Article

\title{
The predictive model of citizens' attitudes about the risks of introducing the death penalty in the legal system: a case study of Serbia
}

\author{
Vladimir M. Cvetković ${ }^{12, *}$, Tatjana Bugarski², Branislav Ristivojević², Goran Milošević́ ${ }^{2}$, Jovana \\ Martinović \\ 1 Faculty of Security Studies, University of Belgrade, Gospodara Vučića 50, 11040 Belgrade, Serbia; vmc@fb.bg.ac.rs \\ 2 Faculty of Law, University of Novi Sad, Trg Dositeja Obradovića 1, Novi Sad 21000, Serbia; \\ t.bugarski@pf.uns.ac.rs; rbrane@pf.uns.ac.rs; g.milosevic@pf.uns.ac.rs \\ 3 Scientific-Professional Society for Disaster Risk Management, Dimitrija Tucovića 121, Beograd; \\ jovanamartino@gmail.com \\ * Correspondence: vmc@fb.bg.ac.rs
}

\begin{abstract}
This paper presents the results of quantitative research regarding the predictive model of citizens' attitudes about the risks of introducing the death penalty in the Republic of Serbia legal system. The research was conducted with the use of a questionnaire that was requested and then collected online from 427 people in June 2021. A multivariate regression analysis was used, identifying the extent to total scores of the main dependent variables (introducing the death penalty; trust in the legal system; advantages of introduction; disadvantages of introduction scores) were associated with five demographic and socio-economic variables: gender, marital, education, income, and age. We tested the central hypothesis of which gender is predicting variables citizens' attitudes about the risks of introducing the death penalty in the legal system of Serbia. The findings revealed that gender and educational level were the most effective predictors of the research variables under question. The majority of respondents support the introduction of the death penalty and the most important predictor of disadvantages of introducing the death penalty in the legal system is age. Based on the findings that there are major differences in the citizens' attitudes about the risks of introducing the death penalty in the legal system, policies, strategies, and regulations must take into account these very important findings.
\end{abstract}

Keywords: death penalty; legal system; risk; citizens; predictive model; Serbia.

\section{Introduction}

The death penalty dates back to the earliest tribes of human history, while debates about the legitimacy and appropriateness of the death penalty are as old as itself (Ehrlich, 1973). Beginning with the period 4000 years ago, when early Babylonian civilizations used formal killing (execution) for acts that violated laws or norms established by the sovereign population, marking them as crimes, as well as periods of criminal expulsion of individuals from the community in ancient Greece, which would due to the lack of shelter, exposure to wildlife and animals, often ended in death, the death penalty, in various forms, followed all societies that had jurisdiction over a particular territory (Colucci, 2020). 
The trend of mass abolition of the death penalty followed in the second half of the 20th century (Mathias, 2013), that, in recent decades, more than 140 countries around the world have abolished the death penalty (Bones \& Sabriseilabi, 2018; Rancourt, Ouellet, \& Dufresne, 2020). The virtual revolution in the way of practicing and experiencing the death penalty, on a global level, was contributed by global cultural factors-drivers such as the global sacralization of the individual, measured as the institutionalization of human rights regimes, as well as the dominant religion in countries (Mathias, 2013). Other countries have restricted its use, primarily due to the growing influence of international human rights law and the availability of prisons as adequate alternative punishments, based on the belief in cruelty, inhumanity, and unnecessary death sentences (Bedau, 2008).

Long-standing arguments on this topic have largely moved in the direction of the deterrent effect of the death penalty on future murders, which are the subject of a considerable amount of theoretical and empirical research (Bailey, 1978; Chen, 2017; Cochran, Chamlin, \& Seth, 1994; Cohen-Cole, Durlauf, Fagan, \& Nagin, 2009; Decker \& Kohfeld, 1990; Dezhbakhsh \& Shepherd, 2006; Forst, 1983; Hjalmarsson, 2009; Narayan \& Smyth, 2006; Passell, 1975; Passell \& Taylor, 1977). Phillips (1980) was among the first to present convincing statistical evidence of the short-term deterrent effect of the death penalty on homicides. Evidence of the deterrent effect of the killings was of great importance in the subsequent review of the states' positions on the issue. Dezhbakhsh, Rubin, and Shepherd (2003) have, in the results of their research, pointed out the strong deterrent effect that characterizes the death penalty, and that each execution of the death penalty results in an average of eighteen fewer murders (with an error of plus or minus ten). A deterrent effect was also found for murders such as passion crimes and the murder of loved ones, as well as for the murders of both African-American and white victims, while a long wait for the death penalty before its execution diminishes the deterrent effect (Shepherd, 2004).

Public opinion and political culture have been identified as significant factors influencing the death penalty rates (Norrander, 2000). Consequently, the growing importance of examining public attitudes about the appropriate treatment of serious criminals, their support or opposition to the death penalty in their country, who influence the policy of the death penalty, and sometimes the overall control of crimes in society, was emphasized. Some beliefs are specific to members of certain religions, cultures, their characteristics, etc., and the literature raises the question of whether people's attitudes toward the death penalty are fundamentally instrumental or expressive, that is, whether public opinion is based on the usefulness of the death penalty system. on the moral implications of the execution of mortal murderers (Brace \& Boyea, 2008; Gau \& Wiecko, 2010).

It is interesting to note that opposition to the death penalty and the opinion that it must be abolished because it undermines human rights as a whole prevail in the public (Rafiq, 2020). The importance of religiosity in predicting the philosophy of punishment is undeniable, although this relationship is complex and nonlinear (Stokes, Haynes, Burdette, \& May, 2020). There are two approaches to explaining public punishment in the literature: a) utilitarian (a means of reducing future crime and controlling offender behavior, usually through deterrence and disabling) and b) retributive (punishment helps clarify moral and normative boundaries) perspective (Gerber, 2021). Ellsworth and Gross (1997) point out that most research seeks to examine whether people's attitudes toward the death penalty are based on emotions or rational arguments.

Starting from the fact that there is no death penalty in the legal system of the Republic of Serbia (Krstić, 2012), but it was applied from the moment the modern state was established in 1804, until 2002 (Tripunović (1988), the main aim of the study is to explore the central hypothesis of which gender is predicting variables citizens' attitudes about the risks of introducing the death penalty in the legal system.

\subsection{Literature Review}


The study of public attitudes towards the death penalty and relevant motives for supporting or opposing its introduction and application in the legislative system of different countries has been a topic of the deep division of interest for decades, while extensive discussions on humanity, justice, and legality of the death penalty continue at all levels. states and societies. The reason for this lies in the fact that, although it is aimed at a relatively small number of people, it directly touches on the deepest question of human life on earth - the question of life and death (Haney, Weill, \& Lynch, 2015). In Texas, in 2002, citizens' trust in the implementation of the death penalty, as well as in support of the death penalty and moratorium, was examined. Although widespread support for the death penalty was found, a high rate of distrust of its use was found, as well as support for the moratorium on the day of execution. Among the mentioned groups, there is also strong support for the death penalty (68\% and $73 \%$, respectively) (Vollum, Longmire, \& Buffington-Vollum, 2004).

Although the questioning of public attitudes on the introduction and application of the death penalty in the legislative system of states is widely discussed in the literature, as a limitation they appear a greater focus on examining the attitudes of students than other members of the community. A review of the literature found largely consistent results of scientific studies on the levels of support for the death penalty in different countries, the factors that encourage detention, and support for the death penalty among different social groups (Trahan \& Laird, 2018).

Starting from the importance of researching the influence of individual differences in personality on the formation of attitudes about the death penalty, Kandola and Egan (2014) found that high extraversion and conscientiousness, low openness and emotional stability, and lower attitudes toward abortion significantly predict support for the use of the death penalty. They also identified greater support for the death penalty among males, who showed greater vengeance in explaining their views (Kandola \& Egan, 2014). Similarly, Robbers (2006) examined the effects of a five-factor model of personality traits on attitudes toward the death penalty, including gender analysis, and found that extroversion and neuroticism were predictors of individual attitudes toward the death penalty while maintaining this effect among gender groups. In addition, according to a previous study, he pointed out the connection between conscientiousness and attitudes about the death penalthy (Robbers, 2006).

Humanistically oriented beliefs, such as empathy, have a significant direct and indirect impact on public support for the death penalty (Unnever, Cullen, \& Fisher, 2005). Empathetic Americans expressed less support for the death penalty because they were politically, liberal, racially, and ethnically tolerant (Unnever et al., 2005). Speaking of empathy, primary importance in the literature is given to ethnocultural empathy, which can reduce the influence of race on the support of the death penalty on insignificance, while, on the other hand, cognitive and affective empathy have not achieved such results (Godcharles, Rad, Heide, Cochran, \& Solomon, 2019). According to the results of a survey conducted on a large number of German respondents, a significant predictor of attitudes towards punishment is the fear of crime, ie different cognitive and emotional responses of respondents to crime, which vary depending on the purpose of punishment and different socio-demographic factors. on the formation of attitudes in men and women (Armborst, 2017). Fear of crime in the neighborhood especially generates a greater willingness to approve the death penalty in public (Keil \& Vito, 1991), while economic anxieties and insecurities, mediated by fear of crime, also have different effects on attitudes towards punishment (Singer, Chouhy, Lehmann, Stevens, \& Gertz, 2020).

As they point out by Peshkopia and Stephen Voss (2016), precise identification and determination of the influence of specific ethnocultural characteristics on attitudes about the death penalty are possible only if there is a constancy of a certain ethnonational culture in different socio-economic and political frameworks. That is why, in their research, they focused on three countries in the Balkans - Albania, Macedonia, and Montenegro - and ethnic Albanians who occupy different socio-political power structures in each of these countries. According to the results, they concluded that the affiliation of the respondents to an ethnic minority or a dominant ethnic group is a significant predictor of their attitudes towards the 
death penalty (Peshkopia \& Stephen Voss, 2016). In their second study, the authors kept the focus on the Balkan countries and found greater opposition to the death penalty among members of minority groups than was the case with members of the majority, in line with the findings of a study in the United States (Peshkopia \& Voss, 2016).

The strong gap between men and women in the field of support for the death penalty has been documented in a large number of studies over a long period (Hurwitz \& Smithey, 1998; Lambert, Clarke, Tucker-Gail, \& Hogan, 2009; Lambert et al., 2016; Whitehead \& Blankenship, 2000). Based on previous research on a higher level of support for the death penalty among men in the United States, Cochran and Sanders (2009) investigated the roots of this division, with gender differences in socioeconomic status, gender inequality, gender socialization, religion/religiosity, political ideology, attitudes about the right to life, fears of crime and victimization experiences, experiences with the criminal justice system, philosophy of punishment and attribution styles were the focus of their study. The most significant results of the study indicated the still strong influence of gender on the support of the death penalty (Cochran \& Sanders, 2009). Although women in Australia have found less support for the death penalty than men, women are more supportive of tougher sentences (Kelley \& Braithwaite, 1990).

Research in southern Africa (Le Roux \& Ambrosio, 2007) confirmed that gender, like race, has the most significant influence on attitudes toward the death penalty. Although the group as a whole had negative attitudes and views on the death penalty, greater positivity towards the death penalty was found in the white group compared to black and colored, as well as among males who had a much more positive attitude towards the death penalty than women (Le Roux \& Ambrosio, 2007). Chintakrindi and Porter (2016) found that sociological factors, such as gender and religious beliefs, are significant predictors of supportive attitudes for both the death penalty and assisted murder. Moreover, gender differences have been found in the sentencing and imposition of the death penalty itself, which are based on persistent cultural gender stereotypes that are often exploited in the media (Lopez, 2014). In contrast to the United States, no correlations were found in China between extrajudicial factors, ie characteristics of the perpetrator sentenced to death (including gender and race), and decisions to impose the death penalty, while legal factors played a dominant role in influencing death penalty decisions ( $\mathrm{Li}$, Longmire, \& Lu, 2018).

Contrary to the results of previous studies, comparing differences in support for the death penalty and belief in criminological ideologies between the sexes among students in Bangladesh, China, Nigeria, and the US, no significant difference was found between men and women overall support levels or reasons. support or opposition to the same between the sexes, except in the United States, where they were very pronounced. Accordingly, the authors concluded that the gender difference in the death penalty may be limited to the United States (Lambert et al., 2014). Similar to heterosexuals, it has been found that most members of the gay and lesbian population support the death penalty (Worthen, Sharp, \& Rodgers, 2012). In addition, the effects of gender and sexual orientation on attitudes toward the death penalty are mediated by political beliefs and empathic concerns (Worthen et al., 2012).

Many studies have indicated significant racial differences in support and use of the death penalty (Applegate, Wright, Dunaway, Cullen, \& Wooldredge, 1994; Arthur, 1998; Baker, Lambert, \& Jenkins, 2005; Cochran et al., 2019; Dambrun, 2007; Foglia \& Connell, 2019; Hannan et al., 2021; Medwed, 2020; Unnever, Cullen, \& Jonson, 2008). Using cross-sectional data from the General Social Survey, 1974-2006, Dotson and Carter (2012) investigated the independent, as well as mutual, influences of race and gender on attitudes toward the death penalty over time and identified significant differences by race but not by gender. While the identified attitudes in attitudes between blacks and whites are stable over time, gender differences in attitudes within different races appear to be more volatile, according to the findings. Examinations of differences in the attitudes of students and residents from settlements with high and low crime on the death penalty and the influence of race on the implementation of the death penalty have yielded the following significant findings: following previous research, on the death penalty, while very 
few differences were found between students and residents living in high- and low-crime settlements (Maggard, Payne, \& Chappell, 2012).

In the United States, where the majority of respondents support the death penalty, a lower propensity to support the death penalty has been identified among blacks and women (Godcharles et al., 2019). Research on the roots of white people's support for the death penalty has indicated that it is shaped by several factors, including social and governmental trust and individualistic and authoritarian values, as well as the local context (Soss, Langbein, \& Metelko, 2003). At the same time, the influence of race is explained by racial prejudices, which appear as a significant predictor of white people's support for the death penalty, and black proximity to housing, which, according to the findings, works to polarize white people's opinions following racial attitude. As the percentage of blacks in the district grows, so does the impact of racial prejudice on white support for the death penalty (Soss et al., 2003). Focusing on the link between racial prejudice and support for the death penalty in France, Dambrun (2007) found that attributing criminal traits to Arabs or crime-based prejudice significantly mediates the relationship between racial prejudice and support for the death penalty.

In addition to the racial and gender influences widely discussed in the literature, Phillips (2009) pointed to the unjustly neglected issue of the impact of a victim's social status on the death penalty, or the district attorney's decision to seek the death penalty and the jury's decision to impose a sentence. According to the findings, he confirmed his hypothesis about the strong influence of the victim's social status on the final state sanction. Namely, a higher probability of searching for the death penalty was found for victims of high social status who were respectable, integrated, sophisticated, and conventional (Phillips, 2009). When it comes to education, the results are inconsistent. For example, Manyok (Manyok, 2018) found that there is a link between the level of education and support for the death penalty and that with an increase in one level of education, the level of support for the death penalty decreases. In contrast, Thinley and Ziegler (2020) indicated that education, like religiosity, does not affect attitudes toward support for the death penalty, while D'Agostino, Sironi, and Sobbrio (2018) identified generally requirements for lenient sentences for crimes among highly educated people living in less corrupt countries.

The findings of recent research represent the public's attitude towards the death penalty, in essence, as a value, not an instrumental one (Trahan, 2017). Of particular interest is the similarity, and, it seems, the contradiction, of the public's views on abortion and the death penalty, that is, the point at which strong support for the death penalty and equally strong opposition to abortion come together. Wiecko and Gau (2008) started from the question of how killing in one context (death penalty) is considered justified, and in another (abortion) is marked as a sin by the public, and found that the most important predictor of membership in a life group / the death of the desire to see criminals punished in combination with a literal orientation toward the Bible. They also pointed out that the mentioned group makes up $5 \%$ of the American population, and, undoubtedly, their beliefs and attitudes, generate certain consequences on the crime control policy in America (Wiecko \& Gau, 2008).

In line with the results of a recent study conducted by Dierenfeldt et al. (2020), to address shortcomings in the literature on the perception of the death penalty concerning sexual crime in different age categories, biological sex, political affiliation, college, fear of crime and parents' level of education were identified as the most significant factors influencing perception in all age categories of victims (Dierenfeldt et al., 2020).

Given that there has been a steady increase in support in America since 1966 when it was at a record high in the mid-1990s (Ellsworth \& Gross, 1997), it represents the most fertile ground for scientific research. Consequently, surveys of changes in public opinion on the death penalty and the factors that motivate them indicate that support for the death penalty may be triggered by events that take place over time, as well as vary in different cohorts as a result of cohort-specific socialization processes, demographic change and formative events that are specific to each generation. Anderson et al. (2017) examined changes in attitudes about the death penalty over time and among gender groups, when they found curvilinear 
effects on age, strong menstrual effects, and weak cohorts in support of the death penalty. Updegrove (2019) emphasizes that, in the context of multicultural countries, such as the United States, it is necessary to take into account the cultural context when examining public attitudes towards the death penalty. When it comes to Brazil, the frequency of killings, feelings of insecurity, and perceived institutional legitimacy are the most important factors influencing the strong support for the death penalty there (Boateng \& Dzordzormenyoh, 2021). In addition, ethnic and religious affiliation and religiosity have been identified as factors influencing public attitudes in Brazil towards the death penalty (Boateng \& Dzordzormenyoh, 2021).

Although a significant number of studies have examined public opinion on the death penalty in the United States, scientists are paying increasing attention to examining the issue in Eastern countries, such as Japan and China. While retaliation and instrumental perspectives are the leading creators of attitudes toward the death penalty in the United States, predictors of attitudes toward the death penalty in China, where there is strong support for it, are both instrumental and retributive perspectives, with the former being stronger. The mentioned data were generated by surveying regular citizens from different fields and occupations (Jiang, Lambert, \& Nathan, 2009). According to the findings of research conducted by $\mathrm{Wu}$, Sun, and $\mathrm{Wu}$ (2011), Chinese students, compared to the Americans, show a higher level of support for the death penalty, while, as factors shaping the attitudes of American and Chinese students identified gender issues, victimization, and criminal justice, as well as certain differences in countries, such as fear of crime (which influenced the support of Chinese students) and focus on crime control (influenced American support) (Wu et al., 2011). Similar results were found by comparing the levels of support for the death penalty and attitudes among students in China, Japan, and the United States (Jiang, Lambert, Wang, Saito, \& Pilot, 2010), indicating the highest level of support for the death penalty among Chinese students, followed by Japanese and American. For U.S. respondents, retaliation was the strongest reason to support the death penalty, and execution barbarism was the strongest reason to oppose the death penalty (Jiang, Lambert, et al., 2010). Although high support for the death penalty was found in the city of Zhejiang in China (more than $72 \%$ ), without any specification of the type of crime, compared to students, a higher probability of support was identified among citizens of the general population. The study's findings also indicated the greatest support for the death penalty for murder in both groups studied, as well as the existence of similar and different reasons for attitudes toward the death penalty between students and regular citizens (Jiang, Hu, \& Lambert, 2018).

Jiang et al. (2010) also found a high degree of support for the death penalty among students in Japan, while deterrence, retaliation, the barbarism of killing, belief in wrong condemnation, and rehabilitation were highlighted as dominant predictors of their perception. In addition, based on the Japanese General Social Survey on a representative sample of adults (Andreescu \& Hughes, 2020), it was found that opponents of the death penalty are less likely than conspirators to have criminal views at all or express some dissatisfaction with the government crime control expenditures. According to the results of their study, proponents and opponents of the death penalty are not distinguished by instrumental factors (fear of crime and victimization), symbolic factors (trust in the judiciary, police, and institutional), and gender. A significant finding of a study conducted by Andreescu and Hughes (2020), which calls into question the strong public support for the death penalty in Japan, is the greater connection and similarity of the views of those who did not agree or disagree with the death penalty. They also found high ambivalence among the population regarding the use of the death penalty, despite strong support (65.2\%), as well as hesitation and reluctance to recommend the death penalty if they were elected to serve in the newly established system of civil judges (Andreescu \& Hughes, 2020).

The conclusions of a study conducted in Taiwan, whose public opinion is still insufficiently researched, emphasize the important role of "conflict of values" in attitudes about the death penalty, its abolition, and alternatives, and that recognizing supporters of public attitudes such as value conflicts, moral psychology, and ambivalence essential to better understand debates and divisions concerning 
opposition and support, retention and abolition of the death penalty (Jou \& Hebenton, 2019). Cao, Lai, and Huang (2020) pointed out that instrumental sources are the most important sources of support for the death penalty policy there and support for the Ministry of Justice's enforcement policy, which includes faith in the deterrent effect of the death penalty and belief in a "strict to crime" approach. "As a general remedy for crime. In contrast, those who believe in the effectiveness of rehabilitation tend to oppose the death penalty policy (Cao et al., 2020).

A 2008 study by Lambert, Hogan, et al. (2008) points to differences in the attitudes of criminal justice students and other public university students in the Midwest, on various relevant issues of the death penalty and reasons for support. opposition to the same. According to them, criminal justice students are more inclined to believe in the deterrent effect of the death penalty and support revenge for the death penalty, which has proven to be the main reasons for supporting the death penalty, while other students are more committed to the ethics of care and mercy. stood out as the leading reason for opposing the death penalty (Lambert, Hogan, et al., 2008). These insights are corroborated by a study conducted by Kennedy and Tripodi (2015) and its results indicated a low level of support for the death penalty among social work students, which decreased when alternative sentences were imposed, with the least support found for vignettes. In contrast, $52.6 \%$ of students enrolled in three courses in criminal justice at the Public University of Michigan, when expressing views on the return of the death penalty to the state after its abolition, expressed support, while $45.7 \%$ of them opposed the renewal of death penalty. Similar religious, economic, and moral reasons were found among both groups of respondents on the renewal of the death penalty in Michigan (Adinkrah \& Clemens, 2018). Addressing the same issue, in support of the reintroduction of the death penalty in Nebraska, Kort-Butler and Ray (2019) found that advocates of the death penalty expressed greater anger over crime and distrust of the government regarding criminal justice, but considered that the death penalty was applied more fairly, compared to other groups (KortButler \& Ray, 2019). Starting from the argument that supports the return of the death penalty could reflect a protest against an unreliable justice system, Peshkopia and Trahan (2020) conducted research in Albania and identified two significant predictors of population support for the return of the death penalty. and skepticism about the conditionality of membership in the European Union (EU) as a driver of democratization of the country (Peshkopia \& Trahan, 2020). When it comes to the reasons for retaining the death penalty in a small number of countries, differences in political structures stand out as leading in the literature. In particular, a higher probability of retaining the death penalty has been identified in countries with two political parties than in countries with more political parties (Van Koppen, Hessing, \& De Poot, 2002).

South Korean public attitudes toward support for the death penalty are overwhelmingly positive $(83 \%)$, with a positive link to support for deterrence and retaliation, while factors such as the gravity of the crime, neighborhood security, innocence, and the brutality effect are negatively related. with support for the death penalty (Choi, Jiang, \& Lambert, 2019). In India, among the student population, certain variations in the degree of support for the death penalty have been observed. According to the findings, $44 \%$ of the surveyed population reported some level of opposition to the death penalty, with morale and the belief that deterrence can be achieved by imposing life sentences without parole identified as the dominant reasons for opposition. On the other hand, $43 \%$ reported some level of support, highlighting revenge, instrumental goals, and disability as the most significant reasons for support. In addition, $13 \%$ of the student population expressed insecurity on the issue (Lambert, Pasupuleti, Jiang, Jaishankar, \& Bhimarasetty, 2008).

Marshall's hypothesis presents support for the death penalty as a reflection of the ignorance of its effects, and implies that support would be greatly reduced under the influence of better public awareness of the pragmatic aspects and reality of the death penalty itself, including lack of appropriate death penalty effects, racial and gender discrimination, increased costs and the risk of execution of innocent people (Trahan, 2017), while at the heart of the elaboration probability model lies the argument that new 
information and knowledge could have a greater impact on the attitudes of individuals who share a greater need for knowledge (Mannes \& Ingaglio Jr, 2015). Nevertheless, Vollum, Mallicoat, and Buffington-Vollum (2009) found that, despite the widespread acceptance of critical information on the death penalty, there is very little likelihood of the impact of this information on support for the death penalty. The findings of their research confirm the value character of attitudes towards the death penalty, and not instrumental or rational, and indicate that the value-oriented attitude towards the death penalty is a significant predictor of such receptivity and variability of attitudes (Vollum et al., 2009). In addition, and line with the findings of previous research on the impact of information on attitudes about the death penalty, Cox (2013) emphasized the inadequacy of exposure to new information on the death penalty in terms of causing changes in their attitudes, although students have limited knowledge.

Contrary to previous insights, the findings of research conducted by Lambert et al. (2011), to examine the impact of information on support for the death penalty, along with prior knowledge, personal characteristics, and religious factors, suggest that information on deterrence and innocence lead to a reduction in support for the death penalty and views on the death penalty, and that the information presented may have different effects among different subgroups of people (Lambert et al., 2011). Instead of using classroom-based factual materials, the use of emotional film as an incentive to portray misconduct has proven to be an effective method of changing people's attitudes toward the death penalty, reducing support for it (Mannes \& Ingaglio Jr, 2015).

The discourse on criminal justice in the United States is increasingly revolving around wrongful convictions (Norris \& Mullinix, 2020). Condemnation of factually innocent persons undermines the legitimacy of criminal justice more than any other issue of public importance while recognizing the nature and frequency of such phenomena leads to public support for reforms of the criminal justice system (Zalman, Larson, \& Smith, 2012). Recognizing the shortcomings of research into the impact of general information on innocence on attitudes toward the death penalty, $\mathrm{Wu}(2021 \mathrm{~b})$ went a step further and in their experiment examined the impact of different estimates of illegal or misconduct rates on public opinion on the death penalty. According to the findings, the respondents' awareness of the higher rate of illegal convictions $(4.1 \%)$ predicted a very small chance that they would support the death penalty compared to the uninformed, while knowing the error rate of $1 \%$ this was not the case, ie no impact on support for the death penalty in the mentioned group of respondents. The authors concluded the important role of accurate assessment of the rate of wrongful convictions in changing people's attitudes and opinions about the death penalty (S. Wu, 2021b). As Wu (2021a), points out, the respondents' belief in the existence of wrongful convictions and general concern about the innocence of convicts is not important in terms of support/opposition to the death penalty, but their belief in their frequency. He found a negative link between support for the death penalty and the rate of wrongly convicted people $(\mathrm{Wu}$, 2021a). Similarly, Norris and Mullinix (2020) have shown that presenting the actual number of exemptions frees up support for the death penalty and undermines trust in the justice system, but fails to gain support for police reform or increase personal concern about wrongful convictions.

When it comes to the stability of informed opinions over the years and the specific reasons that encourage them, Bohm, Vogel, and Maisto (1993) pointed out the following: "(1)" abstract "opinions about the death penalty have changed significantly by exposing classrooms ", but after two or three years they" recovered "close to their starting positions before the test; (2) opinions on the death penalty on "personal participation" did not change significantly from pretest to posttest to follow-up; and (3) the level of agreement with seven of the eleven grounds for an opinion on the death penalty changed significantly between pretest and posttest, but subsequently "recovered" to the initial pre-test agreement level; the level of agreement for two reasons changed significantly between pretest and posttest but remained relatively stable between posttest and follow-up, and the level of agreement for the other two reasons remained relatively stable over three-time points. " (Bohm et al., 1993). 
Among criminal justice practitioners across North Carolina, USA, support for the continued use of the death penalty prevailed, but at the same time, they were aware and agreed that innocent people had been executed before and were on death row today (Hughes \& Robinson, 2013). Griffin (2021), comparing the reasons for support or opposition to the death penalty among American criminologists and those in the general public, found a high probability of opposition to the death penalty among experts, while the most common reasons for the opposition in both groups were moral beliefs. errors in the system and the unfair application of the death penalty. On the other hand, simple retributive justice was the dominant reason for supporting the death penalty, both among the general population and among a small minority of experts who expressed it (Griffin, 2021). In the Midwest, the attitude of prisoners towards the death penalty was investigated, to determine whether individual and social characteristics are predictors of support for the death penalty. On that occasion, it was reported that a small majority of respondents opposed the death penalty (53\%), which was significantly mitigated for crimes such as serial killing and child abuse. The belief that the death penalty prevents violent crime, advocating for the death penalty of family members, and a high score on the Alpha scale (a measure that assesses the identification of prisoners with violent and aggressive aspects of hegemonic masculinity) are the most important predictors of support for the death penalty among prisoners (Steele \& Wilcox, 2003).

Examinations of the relationship between religious and demographic factors and attitudes toward the death penalty have yielded insights into the differences between those who advocated the death penalty and those who doubted it in terms of gender, affiliation, fundamentalism, evangelization, literal biblical interpretation, and belief in God's attitude. towards murders and perceptions of how their religious groups feel about the death penalty (Miller \& Hayward, 2008). Wozniak and Lewis (2010), by controlling religious beliefs, religious behavior, and race, found a higher probability of supporting the death penalty in members of any Christian denomination compared to nonreligious individuals. In contrast, members of different Christian religious traditions have no greater or lesser chance of favoring the death penalty than other Christian affiliates (Wozniak \& Lewis, 2010).

Despite inconsistent findings (Baker \& Booth, 2016; Grasmick, Bursik Jr, \& Blackwell, 1993; Grasmick, Cochran, Bursik Jr, \& Kimpel, 1993; Hanslmaier \& Baier, 2016; Unnever \& Cullen, 2006) over the past decade, Christian fundamentalism is often associated with support for the death penalty (Rade, Holland, Gregory, \& Desmarais, 2017), primarily because of their inherent conservative religious beliefs that justify the use of the death penalty (Unnever \& Cullen, 2006). Lytle and ten Bensel (2016) conducted a study to determine the relevance of Christian fundamentalism in terms of attitudes towards the death penalty compared to those of a non-religious nature and, on that occasion, found that Christian fundamentalism, which identified itself, although not biblically literal or religious name, remained a significant predictor of attitudes toward the death penalty when attitudes toward equality of LGBT marriages were included in the model.

In India, among students from the Hindu community in Karnataka, who were asked to assess the appropriateness of the death penalty in the various scenarios presented to them, there was relatively high support for the death penalty, while the majority view was that the appropriateness of the death penalty depended on several factors. the type of criminal offense committed and the level to which the guilt of the accused has been established (Kamble \& Mullet, 2016). In addition to the above, the following three factors also varied in the scenarios: the defendant's sympathy for the victims, the defendant's predecessors (whether or not he has already committed crimes), and the level of crime in the area where the crime was committed (Kamble \& Mullet, 2016). Unnever, Cullen, and Bartkowski (2006) point out that the nature and intensity of an individual's relationship with God create "a transposed cognitive scheme that shapes people's attitudes toward public policies, such as the execution of convicted murderers." Therefore, they explored the connection between the support of the death penalty and a close personal relationship with a kind, ie God full of love, who forgives and shows unconditional love and mercy. On that occasion, controlling through other known predictors of attitudes about the death penalty and through religious 
factors, they identified a lower probability of supporting the death penalty among Americans with a personal relationship with a kind God (Unnever et al., 2006). Similar results were found in a large representative survey of German respondents (Hanslmaier \& Baier, 2016). Namely, less support for the death penalty and less "punishment" was found among respondents who have an image of God as a God who loves (Hanslmaier \& Baier, 2016). Also, Baker and Whitehead (2020) emphasized the importance of believing in a male God in terms of supporting stricter social policies aimed at criminals. As Webster and Saucier (2013) point out, a higher degree of belief in "pure evil" is associated with greater support for the death penalty, while a higher degree of belief in "pure good" leads to opposition to violent relationships and torture.

In addition to individual and cultural factors influencing attitudes toward the death penalty that have been the focus of previous research, Williams, Votruba, Neuberg, and Saks (2019) pointed to the important role of environmental characteristics in shaping punishment strategies, through the adaptation of individuals to resource availability in their environment. The results of the study indicate that indicators of lack of resources predict the presence of the death penalty, while support for the death penalty increases with the activation of residents' concerns about scarcity, and this effect is statistically mediated by reduced willingness to risk repeated offenses (Williams et al., 2019).

Recognizing the significant lack of social capital research as a determinant of attitudes toward the death penalty, Mangum (2019) conducted a study and found an inverse relationship between social capital and people's support for the death penalty. Experienced and expected future economic instabilities at the personal and social level are negatively related to support for the death penalty, but this relationship is conditioned by the demographic data of the respondents (Lehmann \& Pickett, 2017). Hartnagel and Templeton (2012) also did not find significant indirect effects of economic security on attitudes toward the death penalty. Nevertheless, the results of their study provide significant insights into the role of emotional reactions to crime, especially anger, in explaining criminal attitudes (Hartnagel \& Templeton, 2012). Research on the impact of descriptive and normative economic individualism, ie the belief of individuals about responsibility for their own economic well-being on criminal attitudes, has given insights into the existence of a significant and positive relationship between normative and descriptive economic individualism and support for harsher sentences and the death penalty (Kornhauser, 2015).

An unavoidable issue in a wide range of scientific studies is the relationship between education and attitudes towards the death penalty (Kuehn, Ridener, \& Scott, 2018). Contrary to previous insights into uninformed public prejudice as a source of public support for the death penalty (Chan, Tan, Lee, \& Mathi, 2018; Cochran \& Chamlin, 2005). Liu (2021) found that greater support for the death penalty was widespread among the elite, ie residents with higher education in China. He then pointed to the reasons behind this - less knowledge and less sympathy for criminals (mostly from poor groups) among the elite, while, on the other hand, political ideology and fear of crime play no role in identifying support for the death penalty among the elite. Hessing, de Keijser, and Elffers (2003) also pointed out that proponents of the death penalty in the Netherlands are poorly educated and younger individuals. In Russia, there is a trend of humanization of public awareness of youth related to the level of education, as indicated by the results of research conducted by Kuzina and colleagues (Kuzina, Cherkasova, Artyukhin, Saraev, \& Comartov, 2020).

Britto and Noga-Styron (2014) found that more frequent viewing of police reality shows, which lead to support for the death penalty, is present in less-educated individuals. On the other hand, those with higher education were more likely to listen to the radio, while education and support for the death penalty were negatively linked (Britto \& Noga-Styron, 2014). Execution videotapes played by respondents played a significant role in reducing support for the death penalty (Howells, Flanagan, \& Hagan, 1995). Essays on wrongful convictions had the same effect among students, except in those with a conviction of audacity who were still more likely to support the death penalty (Liang, Liu, \& Lu, 2019). 
Although findings on the negative relationship between education and support for the death penalty support the long-standing fight against the death penalty, Hall (2004) points out that older Americans are less likely to support the death penalty than younger Americans. Besides that, Tedrow (2016) found a higher probability of favoring the death penalty among veterans compared to non-veterans. Vito, Keil, and Andreescu (1999) pointed out that opposition to the death penalty is more common among women, the elderly, the highly educated, and minority respondents, while the stability of support for the death penalty is associated with an increase in education and income. The authors also pointed out that more frequent re-examination of one's support and changes in attitudes towards the death penalty due to facing the alternative is present in women, minorities, and people over the age of 50 (Vito et al., 1999).

\section{Methods}

This study with quantitative research examines an explanatory and predictive model of citizens' attitudes about the risks of introducing the death penalty in the legal system (Figure 1). The research was conducted with the use of a questionnaire that was requested and then collected online from 427 people in June 2021. The main question of the study is to explore the central hypothesis of which gender is predicting variables citizens' attitudes about the risks of introducing the death penalty in the legal system.

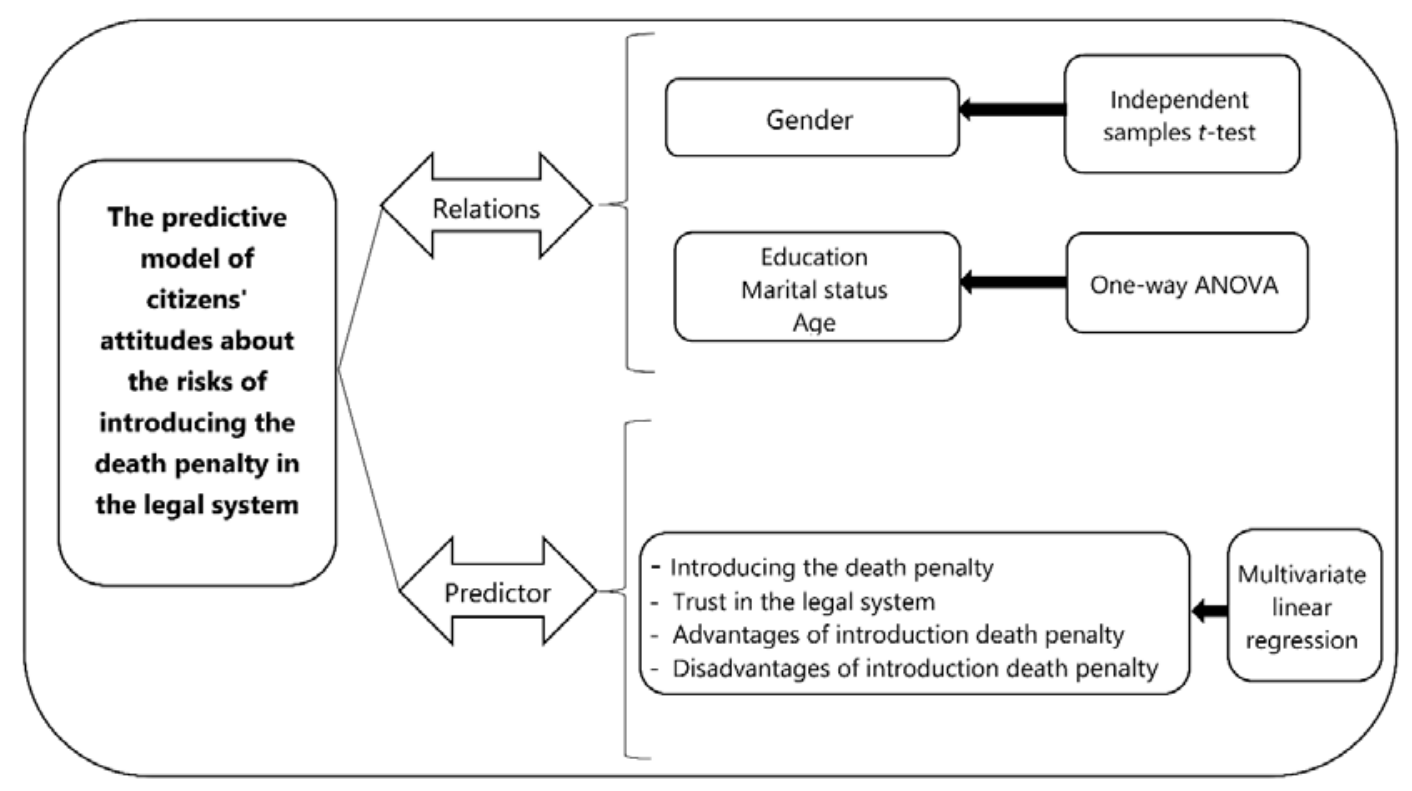

Figure 1. Research design.

\subsection{Study area}

The Republic of Serbia, which spans an area of $88.499 \mathrm{~km} 2$, is situated at the crossroads of Middle and South-Eastern Europe in the Southern Pannonian Plain and the central Balkans. It is bordered on the north by Hungary, the northeast by Romania, the southeast by Bulgaria, the south by North Macedonia, the southwest by Montenegro, and the west by Croatia and Bosnia and Herzegovina (Cvetković, Nikolić, Nenadić, Ocal, \& Zečević, 2020; Cvetković \& Martivnović, 2021; Janković, 2021).

There is no death penalty in the legal system of the Republic of Serbia, but it was applied from the moment the modern state was established in 1804 until 2002 (Krstić, 2012). It was officially abolished from 
federal legislation in 1993, but it was left as a possibility for federal criminal codes. Federal units used that possibility and the death penalty was prescribed only for two offenses in criminal codes of federal units, namely grave murder, and aggravated robbery with murder. After the amendment of the federal Criminal Code in 2001, it was erased even as a possibility, and it was replaced with 40 years of imprisonment.

It was finally abolished from the criminal codes of federal units in 2002. Alongside usual arguments for the abolishment of the death penalty, there were two additional arguments in Serbia. Firstly, it is unacceptable to have the death penalty for grave murder just because it was in the jurisdiction of federal units, but not for genocide or war crimes that were in the jurisdiction of the federation. Secondly, there was no reason not to follow the trend of the abolishment of the death penalty that had long been present in Europe before 2002 (Stojanović, 2013, p. 2395-296). Numerous international conventions have been signed (Second Optional Protocol to the International Covenant on Civil and Political Rights, 6 September 2003 and Protocols Nos. 6 and 13 to the European Convention on Human Rights, 3 March 2004) prohibiting the imposition of the death penalty in the RS. Also, the provisions of the RS Constitution (2006) state in Article 24 that human life is inviolable. As Tripunović (1988) points out, the High Court was competent to execute the death penalty and it was executed without the presence of the public in the early morning hours and outside populated areas, and according to the Instruction on the Execution of the Death Penalty, prosecutor, prison warden, and doctor.

\subsection{Socio-Economic and Demographic Characteristics}

The sample was convenient and not necessarily representative of the Serbian population because an initial invitation to participate in an online questionnaire was posted on social media and distributed to the authors' connections and their friends. A total of 580 people agreed to take part in the study, with 467 agreeing and 113 refusing (so the total response rate was 80.51 percent). Of the total number of respondents who agreed to participate in the survey, 427 respondents completed the survey questionnaire, 40 respondents did not fill (the completion rate was $91.43 \%$ ). The sample was $44.5 \%$ male and $55.5 \%$ female (women $51.3 \%$ and men $48.7 \%$ of the total country population - Statistical Office of the Republic of Serbia, 2020), with an average age of 28 years (country - men 41.2 and women 43.9 ). Of the participants, $35.1 \%$ were between 18 and 30 years of age, 28.1\% were between 31 and 45 years, 25.7\% were between 46 and 64 years, older than 65 were $11 \%$. Married persons accounted for $36.5 \%$ of the study, while $29.7 \%$ were single. The majority of respondents $58.6 \%$ were with low income and with secondary school (grade $8-9$ ) $46.8 \%$ (Table 1).

Table 1. Basic socio-economic and demographic information of respondents $(n=427)$.

\begin{tabular}{llcc}
\hline \multicolumn{1}{c}{ Variable } & \multicolumn{1}{c}{ Category } & (f) & $\%$ \\
\hline \multirow{2}{*}{ Male } & Male & 190 & 44.5 \\
& Female & 237 & 55.5 \\
\multirow{4}{*}{ Age } & $18-30$ & 150 & 35.1 \\
& $31-45$ & 120 & 28.1 \\
& $46-64$ & 110 & 25.7 \\
\multirow{4}{*}{ Marital status } & In connection & 47 & 11 \\
& Single & 127 & 29.7 \\
Education & Married & 97 & 22.7 \\
& Divorced or widow & 156 & 36.5 \\
& Secondary Sch. (grade 8-9) & 200 & 46.8 \\
\hline
\end{tabular}




\begin{tabular}{llcc} 
& High school (grade 11-12) & 68 & 15.9 \\
& Undergraduate & 105 & 24.5 \\
& Master/doctorate & 54 & 12.6 \\
Income & Low income & 250 & 58.6 \\
& High income & 177 & 41.4 \\
& TOTAL & 427 & 100 \\
\hline
\end{tabular}

\subsection{Questionnaire Design}

Several published survey approaches were consulted (Haney et al., 2015; Trahan \& Laird, 2018; Vollum et al., 2004) (Kandola \& Egan, 2014) (Hurwitz \& Smithey, 1998; Lambert et al., 2009; Lambert et al., 2016; Peshkopia \& Stephen Voss, 2016; Unnever et al., 2005; Whitehead \& Blankenship, 2000) and adapted to the conditions of the Serbian demographic and socioeconomic status (Appendix A). In June 2021, a pilot pretest of the questionnaire was conducted in Belgrade (Central Serbia) with 30 participants to assess the questionnaire's comprehensibility and efficiency. Closed-ended and five-point Likert scale questions $(1=$ strongly disagree to $5=$ strongly agree) were used to create the structured questionnaire. The first section of the questionnaire included research question about the participants' socioeconomic and demographic characteristics, while the second section included issue questions about (a) introducing the death penalty; b) trust in the legal system; c) advantages of introduction; and d) disadvantages of introduction scores. Our quantitative analysis was consistent with the Helsinki Declaration (Tyebkhan, 2003), which established guidelines for socio-medical research involving human participants.

\subsection{Analyses}

In this research, descriptive statistics were computed for the participants' fundamental socioeconomic and demographic characteristics. To study the linkage between predictors and citizens' attitudes about the risks of introducing the death penalty, t-tests (Kim, 2015), on one-way ANOVA (Heiberger \& Neuwirth, 2009), and multivariate linear regression have been used (Yuan, Ekici, Lu, \& Monteiro, 2007; Tabachnick, Fidell, and Ullman 2007). Given that the preliminary study of the homogeneity of variance (Test of Homogeneity of Variances) revealed a violation of the assumption of homogeneous variance, the findings of the two tests - Welsh and Brown-Forsythe - which are resistant to the violation of the assumption were utilized. All tests were double-tailed, with a $\mathrm{p}<05$ significance. SPSS Statistics were used for statistical analysis (IBxSPSS Statistics, Version 26, New York, NY, USA). The reliability of the overall questionnaire in terms of Cronbach's alpha coefficient is 0.801 The internal consistency of Likert scales for Advantages of introducing the death penalty in legal system Subscale (7 items) is good with a Cronbach's alpha of 0.82, for Disadvantages of introducing the death penalty in legal system Subscale ( items) 0.81. A multivariate regression analysis was used, identifying the extent to total scores of the main dependent variables (introducing the death penalty; trust in the legal system; advantages of introduction; disadvantages of introduction scores) were associated with five demographic and socio-economic variables: gender, marital, education, income, and age (Table 2). We tested the central hypothesis of which gender is predicting variables citizens' attitudes about the risks of introducing the death penalty in the legal system. Previous investigations on the residual scattering diagram (Tabachnick, Fidell, \& Ullman, 2007) revealed that the assumptions of normality (Normal Probability Plot P-P and Scatterplot), linearity, multicollinearity $(r=$ 0.8 ), and variance homogeneity were not violated. The scientific research group review board of the Scientific-Professional Society for Disaster Risk Management and the International Institute for Disaster Research, ID-20082021, accepted the research protocol.

\section{Results}


The results were split into two groups based on the above-mentioned methodological framework and research design:

3.1. The Predictors of citizens' attitudes about the risks of introducing the death penalty in the legal system;

3.2. Results of descriptive statistics and the relations between the variables and citizens' attitudes about the risks of introducing the death penalty in the legal system;

3.3. Gender perspective about citizens' attitudes about the risks of introducing the death penalty in the legal system.

\subsection{The Predictors of citizens' attitudes about the risks of introducing the death penalty in the legal system}

The multivariate regression analyses showed that all variables did not have significant effects on introducing the death penalty in the legal system. On the other side, the most important predictor of trust in the legal system is gender $(\beta=-.229)$, and it explains $5.29 \%$ variance in the score, followed by education $(\beta=-.186,3.09 \%)$. This model $\left(\mathrm{R}^{2}=.095\right.$, Adj. $\left.\mathrm{R}^{2}=.084, F=8.85, t=29.28, p=.000\right)$ with all mentioned independent variables explains the $8.4 \%$ variance of trust in the legal system in charge of enforcing the death penalty. Also, the results of the multivariate regressions showed that the most important predictor for advantages of introducing the death penalty in the legal system is gender $(\beta=$ $-.148)$, and it explains a $1.96 \%$ variance in the score. This model $\left(R^{2}=.028\right.$, Adj. $R^{2}=.017, F=2.43, t=$ $40.53, p=.034$ ) with all mentioned independent variables explains the $1.7 \%$ variance of introducing advantages the death penalty in the legal system. In the end, the multivariate regression analyses showed that the most important predictor of disadvantages of introducing the death penalty in the legal system is age $(\beta=-.229)$, and it explains $2.04 \%$ variance in the score, followed by marital $(\beta=-$ $.136,1.82 \%)$, and education $(\beta=-.099,0.8 \%)$. This model $\left(\mathrm{R}^{2}=.049, \mathrm{Adj} . \mathrm{R}^{2}=.038, \mathrm{~F}=4.38, t=40.53, p=\right.$ .001 ) with all mentioned independent variables explains the $3.8 \%$ variance of introducing disadvantages the death penalty in the legal system (Table 2 and Figure 2).

Table 2. Results of a multivariate regression analysis of introducing the death penalty in the legal system $(n=427)$.

\begin{tabular}{|c|c|c|c|c|c|c|c|c|c|c|c|c|}
\hline \multirow{2}{*}{$\begin{array}{l}\text { Predictor } \\
\text { Variable }\end{array}$} & \multicolumn{3}{|c|}{$\begin{array}{l}\text { Introducing the } \\
\text { death penalty }\end{array}$} & \multicolumn{3}{|c|}{$\begin{array}{l}\text { Trust in the } \\
\text { legal system }\end{array}$} & \multicolumn{3}{|c|}{$\begin{array}{l}\text { Advantages of } \\
\text { introduction }\end{array}$} & \multicolumn{3}{|c|}{$\begin{array}{l}\text { Disadvantages of } \\
\text { introduction }\end{array}$} \\
\hline & $B$ & $S E$ & $\beta$ & $B$ & $S E$ & $\beta$ & $B$ & $S E$ & $\beta$ & $B$ & $S E$ & $\beta$ \\
\hline Gender & -.028 & .016 & -.087 & -.063 & .013 & $-.229^{* *}$ & -.039 & .013 & $-.148^{*}$ & .019 & .014 & .065 \\
\hline Marital & .007 & .015 & .023 & .017 & .013 & .061 & .006 & .013 & .022 & -.039 & .014 & $-.136^{*}$ \\
\hline Education & -.004 & .020 & -.011 & -.062 & .016 & $-.186^{* *}$ & -.002 & .016 & -.006 & -.035 & .018 & $-.099^{*}$ \\
\hline Income & .023 & .025 & .046 & -.012 & .020 & -.028 & -.030 & .020 & -.072 & -.023 & .022 & -.050 \\
\hline Age & .036 & .060 & .030 & -.003 & .050 & -.003 & .018 & .050 & .019 & .160 & .053 & $.151^{*}$ \\
\hline Adjusted $R^{2}$ & & .01 & & & .08 & & & .01 & & & .03 & \\
\hline
\end{tabular}




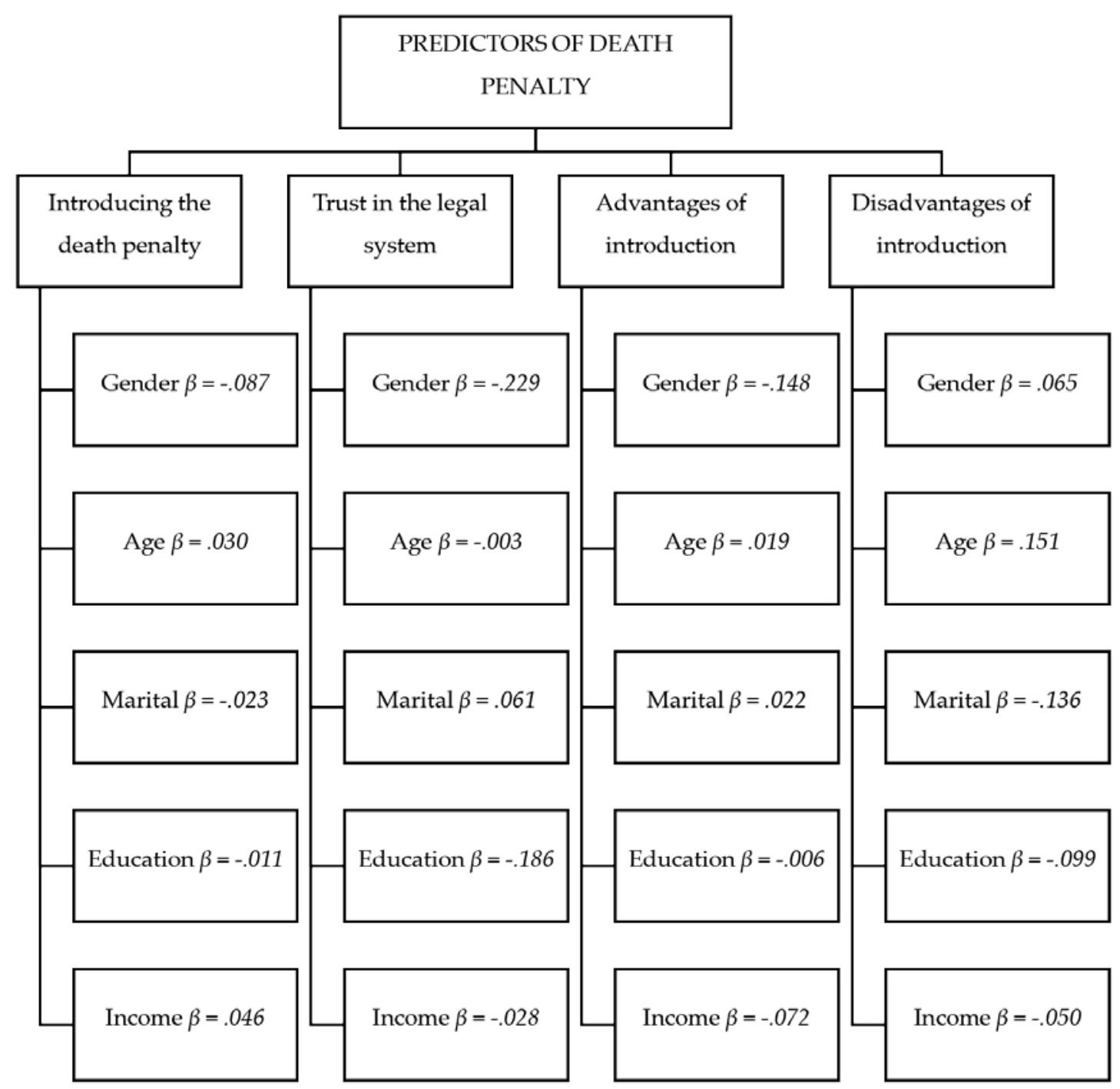

Figure 2. The predictors of introducing the death penalty in the legal system RS

3.2. Results of descriptive statistics and the relations between the variables and citizens' attitudes about the risks of introducing the death penalty in the legal system

When asked whether they support the introduction of the death penalty, $65.6 \%$ of respondents answered positively, while $24.6 \%$ were against and $9.8 \%$ were neutral. On the Likert scale from 1 to $5(x=3.67)$, it was found that $41.5 \%$ of respondents absolutely support the introduction of the death penalty, while $18 \%$ absolutely do not support it. Then, it was found that the largest number of respondents $60.6 \%$ do not trust the legal system of the Republic of Serbia, which is in charge of executing such criminal sanctions $(x=2.38)$ (Figure 3). 


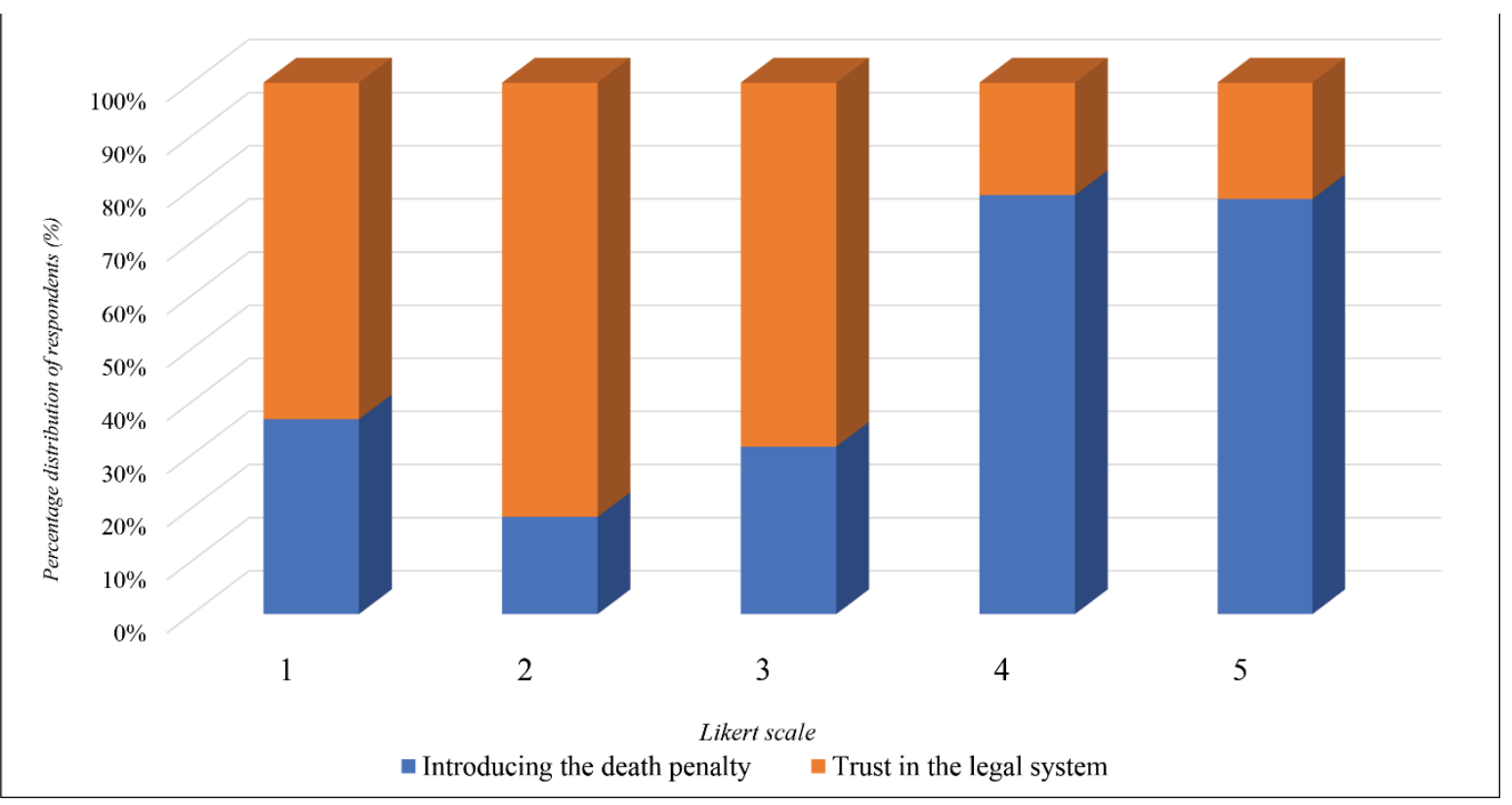

Figure 3. Attitudes of citizens on the introduction of the death penalty and trust in the legal system of the Republic of Serbia.

In the further work, the agreement of the respondents with certain reasons for not introducing the death penalty in the legal system of the Republic of Serbia was determined. In the first place, there is concern about a possible wrongful conviction $(x=3.75 ; \mathrm{sd}=1.50)$, then concern about the impossibility of repeating the procedure $(x=3.23$; $s d=1.58)$; reduction of punishment to naked repression $(x=3.03$; $s d=1.56)$; punishment would be revenge for the perpetrator $(x=3.02$; $s d=1.72)$; preference is given to laws rather than human rights $(x=2.84 ; \mathrm{sd}=1.57)$ and ultimately violations of human dignity $(\mathrm{x}=2.49 ; \mathrm{sd}=1.56)$ (Figure $4)$.

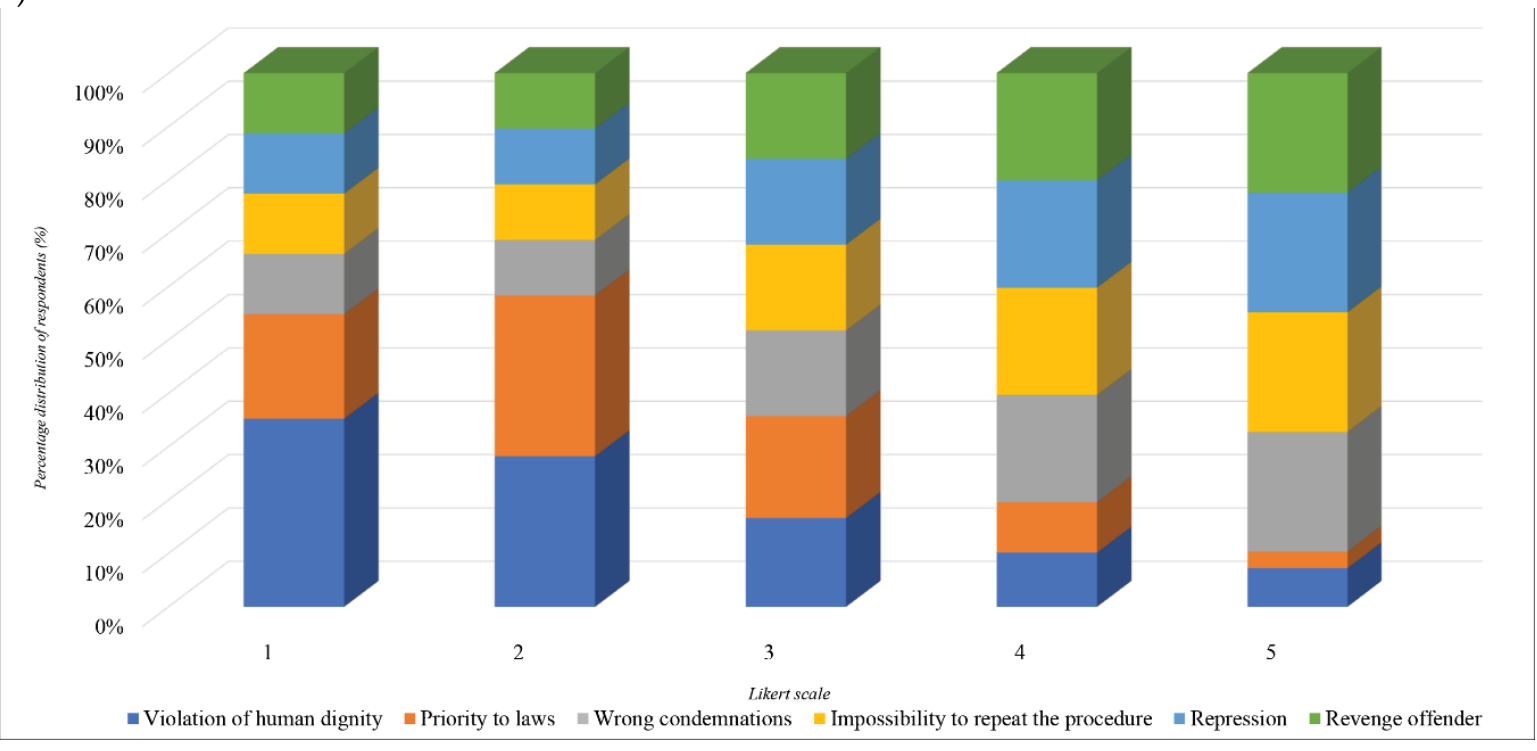

Figure 4. Attitudes of citizens on the reasons for not introducing the death penalty in the legal system of the Republic of Serbia. 
After examining the reasons against the introduction of the death penalty, we examined the reasons that respondents are guided by when deciding to introduce it. It was determined that in the first place are: the impossibility of re-committing the crime $(x=3.98$; $\mathrm{sd}=1.42)$, then deterrence of the perpetrator $(x=3.90$; sd $=1.51)$; better expression of social condemnation for the committed crime $(x=3.77$; $\mathrm{sd}=1.50)$; security improvement $(x=3.72 ; \mathrm{sd}=1.49)$; achieving proportionality and fairness between the committed crime and the gravity of the criminal sanction $(x=3.59$; $s d=1.64)$; economic repercussions $(x=2.92 ; s d=1.45)$; life for life $(x=2.84 ; \mathrm{sd}=1.81)$ (Figure 5).

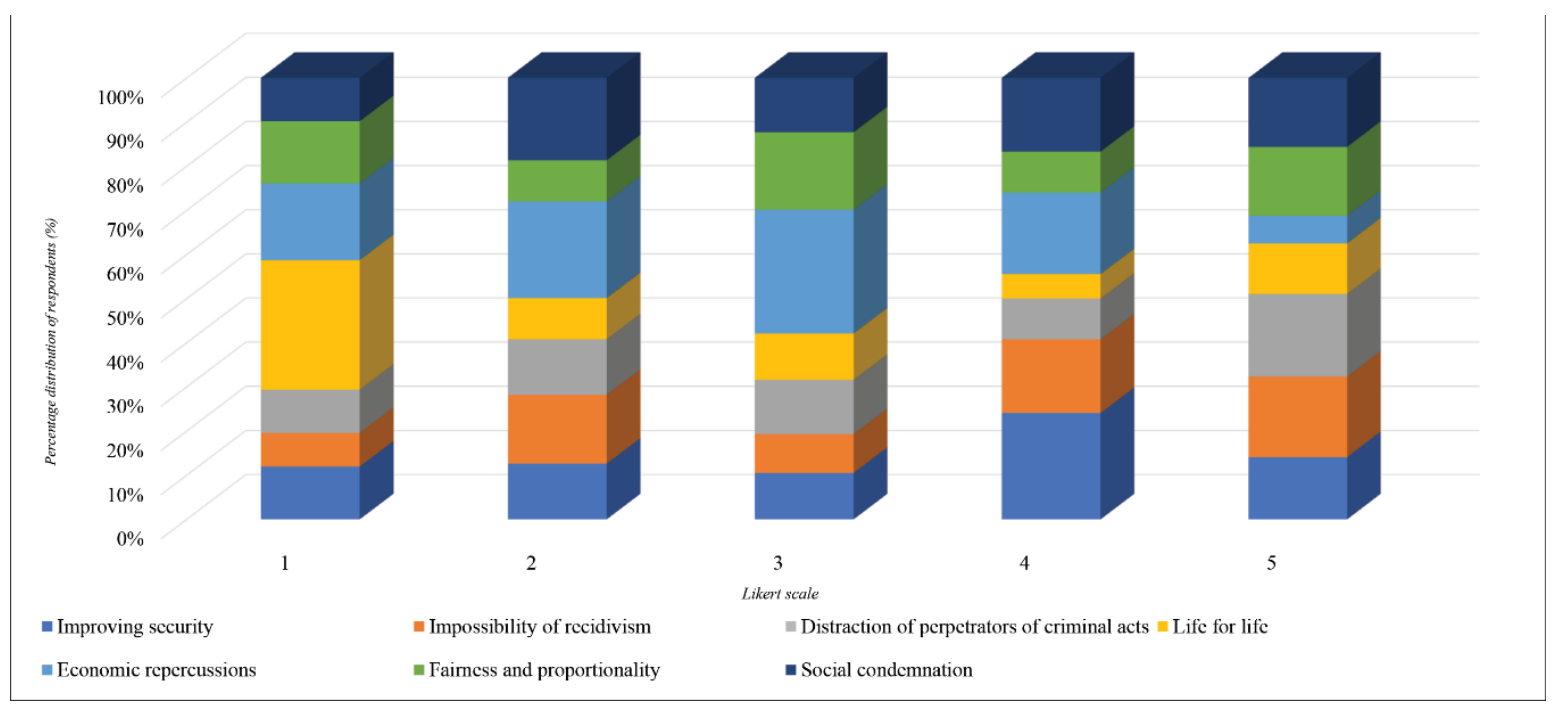

Figure 5. Attitudes of citizens on the reasons for the introduction of the death penalty in the legal system of the Republic of Serbia.

The results of examining the attitudes of respondents on the effectiveness of various entities in the implementation of general prevention of crime show that they mostly assess the level of efficiency of the police $(x=3.24 ; \mathrm{sd}=1.29)$, then the public prosecutor's office $(\mathrm{x}=2.58 ; \mathrm{sd}=1.28)$; courts $(\mathrm{x}=2.12 ; \mathrm{sd}=1.02)$ and media $(\mathrm{x}=2.10 ; \mathrm{sd}=1.35)$ (Figure 6).

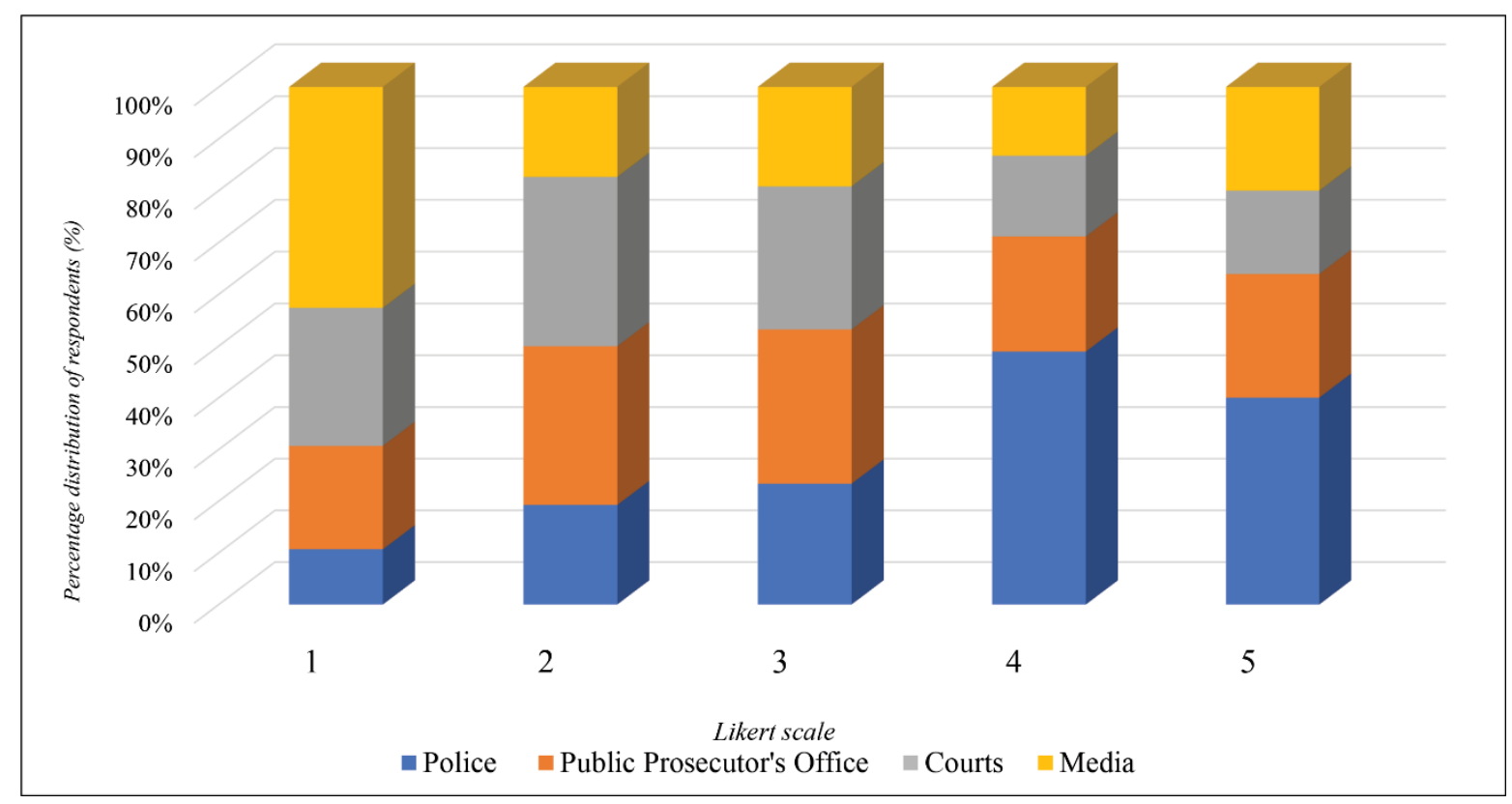


Figure 6. Attitudes of citizens on the efficiency of various entities in the implementation of general prevention of criminal offenses.

The results of the study of the relationship between age and the observed variables show that there is a correlation with trust in the legal system $(r=-.144, p \leq 0.003$ - small correlation), advantages of the introduction death penalty $(r=-.131, p \leq 0.007$ - small correlation), and service efficiency ( $r=-.097, p \leq 0.046$ - small correlation). The obtained results show that with increasing age, trust in the legal system in charge of enforcing the death penalty, support for the introduction of the death penalty, and evaluation of the efficiency of the competent authorities also decreases. When it comes to marital status, no correlation was found with any of the observed variables. Concerning the educational status, a correlation was established with the trust in the legal system $(r=.333, p \leq 0.000$ - average correlation), while with the increase of education, the trust in the legal system in charge of implementing the death penalty grows. In addition, a correlation was found between introducing death penalty and trust in the legal system $(r=.402, p \leq 0.000$ - medium correlation) and with introduction advantages $(r=.709, p \leq 0.000$ - high correlation), and introduction disadvantages ( $r=-.640, p \leq 0.000$ - large correlation). Further analyzes show that respondents who are more supportive of the introduction of the death penalty also have more confidence in the legal system in charge of its implementation. Also, it was determined that the respondents who are in favor of the introduction of the death penalty to a greater extent recognize the advantages of the introduction of the death penalty. On the other hand, respondents who to a greater extent believe that there are shortcomings in the introduction of the death penalty are less supportive (Table 4).

Table 4. Pearson's correlation results between the perception of public nuclear energy and predictor variables.

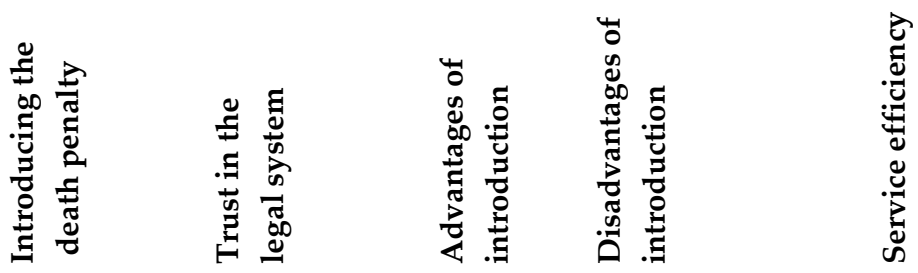

\begin{tabular}{|c|c|c|c|c|c|c|c|c|c|c|}
\hline Variable & Sig. & $\mathrm{r}$ & Sig. & $\mathrm{r}$ & Sig. & $\mathrm{r}$ & Sig. & $\mathrm{r}$ & Sig. & $\mathrm{r}$ \\
\hline Age & .077 & -.086 & $.003^{*}$ & -.144 & $.007^{*}$ & -.131 & .648 & .022 & $.046^{*}$ & -.097 \\
\hline Marital status & .668 & .021 & .357 & -.045 & .939 & .004 & .361 & .044 & .811 & -.012 \\
\hline Education level & .979 & -.001 & $.000^{* *}$ & .333 & .081 & .087 & .933 & .004 & $.009^{*}$ & -.131 \\
\hline Introducing death penalty & 1 & 1 & $.000^{* *}$ & .402 & $.000 * *$ & .709 & $.000^{*}$ & -.640 & .255 & .055 \\
\hline
\end{tabular}

When the association between marital status and different variables of introduction of the death penalty in the legal system was analyzed, it was found that that there is a statistically significant correlation with the following variables: violation of human dignity $(p=0.00)$; laws are preferred to human rights $(p=0.00)$; wrongful condemnation $(p=0.00)$; reduced to mere repression $(p=0.00)$; revenge for the perpetrator $(p=0.00)$; it deters perpetrators of crimes $(p=0.020)$; life for life $(p=0.013)$; economic repercussions ( $p=0.05$ ) (Table 3). Sa ostalim varijablama nije utvrđena statistički značajna povezanost. Further analyzes show that single respondents noted the highest scores for life for life ( $\mathrm{x}$ $=3.19$; $\mathrm{sd}=1.84)$. Married repondents noted the highest scores for arguments: violation of human dignity $(x=2.93$; $s d=1.60)$; laws are preferred to human rights $(x=3.21$; $s d=1.42)$; wrongful condemnation $(x=4.19$; $s d=1.19)$; reduced to mere repression $(x=3.54$; $s d=1.50)$; revenge for the 
perpetrator $(x=3.43$; sd $=1.54)$. Divorced or widow noted the highest scores for arguments: it deters perpetrators of crimes $(x=4.25$; $\mathrm{sd}=1.48)$; economic repercussions $(\mathrm{x}=3.33$; $\mathrm{sd}=1.22)$.

The relationship between education and the variables was determined: trust in the legal system $(p=0.00)$; violation of human dignity $(p=0.00)$; laws are preferred to human rights $(p=0.00)$; impossibility of repeating the procedure $(p=0.018)$; revenge for the perpetrator $(\mathrm{p}=0.01)$; life for life $(p=0.02)$; economic repercussions $(p=0.09)$; expressing social condemnation for a crime $(p=0.07)$; the most serious crimes $(p=0.018)$; police $(p=0.00)$; public prosecutor's office $(p=0.00)$; media $(p=0.018)$ (Table 3). No statistically significant correlation was found with other variables. Further analyzes show that respondents with a university degree noted the highest scores for trust in the legal system $(\mathrm{x}=$ 3.08; $\mathrm{sd}=1.47$ ). Respondents with high school noted the highest scores for arguments: violation of human dignity $(\mathrm{x}=2.55 ; \mathrm{sd}=1.50)$; impossibility of repeating the procedure $(\mathrm{x}=4.27 ; \mathrm{sd}=1.36)$; the most serious crimes $(x=3.82$; $s d=1.34)$; public prosecutor's office $(x=3.27$; $s d=1.22)$; media $(x=2.50$; $\mathrm{sd}=1.29)$. Sa druge strane, fakultetski obrazovani noted the highest scores for arguments laws are preferred to human rights $(x=3.12$; $s d=1.57)$, life for life $(x=3.15$; $s d=1.86)$. Respondents with a master's or doctoral degree noted the highest scores for arguments revenge for the perpetrator $(\mathrm{x}=$ 3.54 ; $\mathrm{sd}=1.79)$; economic repercussions $(\mathrm{x}=3.31$; $\mathrm{sd}=1.54)$; expressing social condemnation for a crime $(\mathrm{x}=4.23$; sd =1.19); police $(\mathrm{x}=3.77$; $\mathrm{sd}=1.12)$.

Considering income level, a correlation was found with the following variables: trust in the legal system $(p=0.00)$; expressing social condemnation for a crime $(p=0.04)$; achieving fairness and proportionality $(p=0.01)$; aggravated murder $(p=0.02)$; the most serious forms of serious crime ( $p=$ 0.00) (Table 3). Further analyzes show that low income respondents noted the highest scores for arguments: expressing social condemnation for a crime $(\mathrm{x}=3.89$; $\mathrm{sd}=1.38)$; aggravated murder $(\mathrm{x}=$ 3.66 ; $\mathrm{sd}=1.53)$; the most serious forms of serious crime $(\mathrm{x}=4.17$; $\mathrm{sd}=1.48)$. High income respondents noted the highest scores for arguments: trust in the legal system $(x=3.24 ; \mathrm{sd}=1.44)$; achieving fairness and proportionality $(\mathrm{x}=3.78 ; \mathrm{sd}=1.67)$.

Table 3. One-way ANOVA results of the relations between the variables of introducing the death penalty in the legal system, and marital status, education level, and age.

\begin{tabular}{|c|c|c|c|c|c|c|c|c|}
\hline \multirow{2}{*}{ Variable } & \multirow{2}{*}{ Mean } & \multirow{2}{*}{$\begin{array}{c}\text { Std. } \\
\text { Deviation }\end{array}$} & \multicolumn{2}{|c|}{ Marital status } & \multicolumn{2}{|c|}{ Education } & \multicolumn{2}{|c|}{ Income } \\
\hline & & & $F$ & $p$ & $F$ & $p$ & $F$ & $p$ \\
\hline Introduction of the death penalty & 3.64 & 1.50 & 1.21 & .299 & .047 & .954 & 2.42 & .069 \\
\hline Trust in the legal system & 2.38 & 1.29 & 1.77 & .172 & 23.78 & $.000^{* *}$ & 11.78 & $.000^{* *}$ \\
\hline Violation of human dignity & 2.49 & 1.56 & 23.48 & $.000^{* *}$ & 10.40 & $.000^{* *}$ & 1.86 & .139 \\
\hline Laws are preferred to human rights & 2.84 & 1.56 & 23.71 & $.000^{* *}$ & 13.54 & $.000^{* *}$ & 1.68 & .171 \\
\hline Wrongful condemnation & 3.75 & 1.50 & 16.31 & $.000^{* *}$ & 1.46 & .234 & 1.90 & .132 \\
\hline Revenge for the perpetrator & 3.91 & 1.46 & 18.48 & $.000^{* *}$ & 6.93 & $.001^{* *}$ & .489 & .961 \\
\hline Improving security & 3.98 & 1.42 & .379 & .685 & 3.03 & .051 & 1.39 & .248 \\
\hline Impossibility to do the work again & 3.90 & 1.51 & 2.71 & .069 & 1.79 & .169 & 1.36 & .260 \\
\hline It deters perpetrators of crimes & 2.84 & 1.81 & 3.98 & $.020^{*}$ & .325 & .723 & 1.13 & .337 \\
\hline Life for life & 2.92 & 1.45 & 4.39 & $.013^{*}$ & 6.72 & $.002^{*}$ & 1.24 & .296 \\
\hline Aggravated murder & 3.36 & 1.53 & 1.99 & .139 & 5.87 & $.003^{*}$ & 5.10 & $.002^{*}$ \\
\hline The most serious crimes & 3.69 & 1.55 & 1.37 & .254 & 4.09 & $.018^{*}$ & 1.51 & .213 \\
\hline The most serious forms of serious crime & 3.24 & 1.29 & 4.21 & $.016^{*}$ & 2.61 & .076 & 8.12 & $.000^{* *}$ \\
\hline Police & 2.58 & 1.28 & 2.00 & .138 & 18.10 & $.000^{* *}$ & 1.87 & .138 \\
\hline
\end{tabular}




\begin{tabular}{|c|c|c|c|c|c|c|c|c|}
\hline Public Prosecutor's Office & 2.12 & 1.02 & 5.68 & $.004^{*}$ & 12.62 & $.000^{* *}$ & 2.23 & .087 \\
\hline Courts & 2.10 & 1.35 & .454 & .636 & 3.94 & .021 & 1.35 & .259 \\
\hline Media & 2.19 & 1.25 & .570 & .566 & 4.13 & $.018^{*}$ & 1.25 & .214 \\
\hline
\end{tabular}

${ }^{*} p \leq 0.05 ;{ }^{* *} p \leq 0.01$.

\subsection{Gender perspective about citizens' attitudes about the risks of introducing the death penalty in the legal system}

The results of the t-test show that there statistically significant difference in the results between men and women in terms of trust in the legal system $(p=0.00)$; violation of human dignity $(\mathrm{p}=0.022)$; revenge for the perpetrator $(\mathrm{p}=0.017)$; improving security $(p=0.000)$; impossibility to do the work again $(p=0.018)$; it deters perpetrators of crimes $(p=0.000)$; expressing social condemnation for a crime $(p=0.010)$; achieving fairness and proportionality $(p=0.000)$; aggravated murder $(p=0.002)$; the most serious crimes $(p=0.000)$; the most serious forms of serious crime $(p=0.027)$; public prosecutor's office ( $\mathrm{p}=0.001)$; courts $(p=0.000)$; media $(p=0.000)$ (Table 3$)$.

Further analyzes of the obtained results show that women $(x=2.59 ; \mathrm{sd}=1.36)$ to a greater extent than men $(x=1.95 ; s d=1.02)$ have trust in the legal system in charge of enforcing the death penalty; as a reason for the introduction of the death penalty they point out improving security (female $-\mathrm{x}=4.00$, $\mathrm{sd}=1.32$; male $-\mathrm{x}=3.15, \mathrm{sd}=1.65$ ); impossibility to do the work again (female $-\mathrm{x}=4.10$, sd $=1.32$; male $-\mathrm{x}=3.75$, sd $=1.58$ ); it deters perpetrators of crimes (female $-\mathrm{x}=4.12$, $\mathrm{sd}=1.34$; male $-\mathrm{x}=3.45$, $\mathrm{sd}=1.72$ ); expressing social condemnation (female $-\mathrm{x}=3.90, \mathrm{sd}=1.46$; male $-\mathrm{x}=3.50, \mathrm{sd}=1.53$ ); achieving fairness and proportionality (female $-\mathrm{x}=3.82$, $\mathrm{sd}=1.52$; male $-\mathrm{x}=3.15$, $\mathrm{sd}=1.77$ ); aggravated murder (female $-\mathrm{x}=3.70$, $\mathrm{sd}=1.48$; male $-\mathrm{x}=3.20, \mathrm{sd}=1.69$ ). Also, they are more for the introduction of the death penalty for the most serious crimes (female $-\mathrm{x}=3.56$, $\mathrm{sd}=1.45$; male $-\mathrm{x}=2.95, \mathrm{sd}=1.63$ ) and the most serious forms of serious crime (female $-\mathrm{x}=3.80$, $\mathrm{sd}=1.48$; male $-\mathrm{x}=3.45$, $\mathrm{sd}=1.66$ ). In addition, they assess the efficiency of public prosecutor's office to a greater extent (female $-\mathrm{x}=2.73$, $\mathrm{sd}=1.30$; male $-\mathrm{x}=2.30$, $\mathrm{sd}=1.19$ ); courts (female $-\mathrm{x}=2.27$, sd =1.08; male $-\mathrm{x}=1.85$, sd =0.85); media (female $-\mathrm{x}=2.25$, sd =1.70; male $-\mathrm{x}=3.30$, sd $=1.74)$. In contrast, men $(x=2.75 ; s d=1.67)$ to a greater extent than women $(x=2.37 ; s d=1.49)$ point out violation of human dignity as a reason for not introducing the death penalty; consider it revenge for the perpetrator (male $-\mathrm{x}=3.30, \mathrm{sd}=1.74$; female $-\mathrm{x}=2.88, \mathrm{sd}=1.70$ ) (Table 3 ).

Table 3. Independent samples t-test results between gender and the variables of introducing the death penalty in the legal system

\section{Gender}

\begin{tabular}{|c|c|c|c|c|c|c|c|c|}
\hline Variable & $\mathbf{F}$ & $\mathbf{t}$ & df & $\begin{array}{l}\text { Sig. } \\
\text { (2-Tailed) }\end{array}$ & Male X (SD) & Female X (SD) & 节 & مेّ \\
\hline Introduction of the death penalty & 41.17 & -1.81 & 425 & .070 & $3.45(1.75)$ & $3.73(1.36)$ & -0.75 & 0.56 \\
\hline Trust in the legal system & 31.49 & -4.87 & 425 & $.000^{* *}$ & $1.95(1.02)$ & $2.59(1.36)$ & -0.26 & 0.35 \\
\hline Violation of human dignity & 9.09 & 2.30 & 250 & $.022^{*}$ & $2.75(1.67)$ & $2.37(1.49)$ & 0.05 & 0.71 \\
\hline Laws are preferred to human rights & .004 & 1.51 & 425 & .130 & $3.00(1.58)$ & $2.76(1.54)$ & -0.72 & 0.56 \\
\hline Wrongful condemnation & 1.25 & .482 & 418 & 630 & $3.80(1.47)$ & $3.73(1.51)$ & -0.23 & 0.38 \\
\hline Impossibility of repeating the procedure & 3.94 & 1.09 & 425 & .273 & $3.35(1.49)$ & $3.17(1.62)$ & -0.13 & 0.49 \\
\hline Reduced to mere repression & 21.75 & -.788 & 404 & .431 & $2.95(1.40)$ & $3.08(1.64)$ & -0.43 & 0.17 \\
\hline Revenge for the perpetrator & .035 & 2.38 & 418 & $.017^{*}$ & $3.30(1.74)$ & $2.88(1.70)$ & 0.07 & 0.77 \\
\hline Improving security & 39.33 & -5.68 & 418 & $.000^{* *}$ & $3.15(1.65)$ & $4.00(1.32)$ & -1.16 & -0.53 \\
\hline Impossibility to do the work again & 10.08 & -2.38 & 425 & $.018^{*}$ & $3.75(1.58)$ & $4.10(1.32)$ & -0.65 & -0.04 \\
\hline It deters perpetrators of crimes & 44.53 & -4.39 & 425 & $.000^{* *}$ & $3.45(1.72)$ & $4.12(1.34)$ & -0.99 & -0.34 \\
\hline Life for life & 11.87 & .906 & 425 & .365 & $2.95(1.91)$ & $2.78(1.76)$ & -0.21 & 0.54 \\
\hline Economic repercussions & .053 & -.179 & 425 & .858 & $2.90(1.45)$ & $2.93(1.45)$ & -0.32 & 0.26 \\
\hline Expressing social condemnation & 4.68 & -2.59 & 418 & $.010^{*}$ & $3.50(1.53)$ & $3.90(1.46)$ & -0.70 & -0.09 \\
\hline
\end{tabular}




\begin{tabular}{|c|c|c|c|c|c|c|c|c|}
\hline Achieving fairness and proportionality & 23.03 & -4.00 & 411 & $.000^{* *}$ & $3.15(1.77)$ & $3.82(1.52)$ & -1.07 & -0.32 \\
\hline Aggravated murder & 19.24 & -3.09 & 418 & $.002^{*}$ & $3.20(1.69)$ & $3.70(1.48)$ & -0.83 & -0.16 \\
\hline The most serious crimes & 6.13 & -3.91 & 425 & $.000^{* *}$ & $2.95(1.63)$ & $3.56(1.45)$ & -0.93 & -0.29 \\
\hline The most serious forms of serious crime & 13.73 & -2.22 & 425 & $.027^{*}$ & $3.45(1.66)$ & $3.80(1.48)$ & -0.68 & -0.02 \\
\hline Police & 9.33 & -.981 & 411 & .327 & $3.15(1.39)$ & $3.28(1.24)$ & -0.40 & 0.14 \\
\hline Public Prosecutor's Office & 6.88 & -3.23 & 418 & $.001^{* *}$ & $2.30(1.19)$ & $2.73(1.30)$ & -0.67 & -0.17 \\
\hline Courts & 26.38 & -3.96 & 397 & $.000^{* *}$ & $1.85(.856)$ & $2.27(1.08)$ & -0.61 & -0.22 \\
\hline Media & 22.72 & -3.27 & 397 & $.000^{* *}$ & 1.79 (1.15) & $2.25(1.41)$ & -0.71 & -0.20 \\
\hline
\end{tabular}

\section{Discussion}

Examining the predictor model of respondents' attitudes towards the introduction of the death penalty, the majority support for the introduction of such a punishment in the legal system of the Republic of Serbia was determined, which is consistent with the findings of studies conducted in Texas (Vollum et al., 2004), China (Jiang et al., 2018), Japan (Jiang, Pilot, et al., 2010) and South Korea (Choi et al., 2019). Gender and then education were identified as predictors of a high degree of distrust in the legal system of the Republic of Serbia, which is responsible for the execution of such criminal sanctions. Also, the most important predictor of the advantages of the introduction of the death penalty in the legal system is gender, and the lack of the introduction of the death penalty in the legal system is age, followed by marriage and education. The obtained results are following the results of certain studies where, for example, Peshkopia \& Trahan, (2020) highlighted the lack of trust in the country's judiciary as one of the predictors of support for the return of the death penalty in Albania. In contrast, Andreescu and Hughes (2020) found that proponents and opponents of the death penalty are not distinguished by symbolic factors such as trust in the judiciary, police, and institutional.

The gap between men and women in the field of support for the death penalty, documented in a significant number of studies (Cochran \& Sanders, 2009; Godcharles et al., 2019; Hurwitz \& Smithey, 1998; Lambert et al., 2009; Lambert et al., 2016; Whitehead \& Blankenship, 2000), is also confirmed by the results of our research. Namely, a higher rate of trust in the legal system in charge of executing the death penalty was identified among members of the female population, while the reasons for the introduction of the death penalty were improved security, inability to do work again, deterring perpetrators, expressing social condemnation, achieving fairness and proportionality, aggravated murder. Also, they are more for the introduction of the death penalty for the most serious crimes and the most serious forms of serious crime. In contrast, men to a greater extent than women point to the violation of human dignity as a reason for not introducing the death penalty; consider it revenge for the perpetrator.

Kandola and Egan (2014) also identified greater support for the death penalty among males, who showed greater vengefulness in explaining their views. Although less support for the death penalty has been found in women in Australia than in the male population, it has been found that women are more supportive of harsher punishments (Kelley \& Braithwaite, 1990). Research in South Africa (Le Roux \& Ambrosio, 2007) confirmed that gender, like race, has the most significant impact on attitudes toward the death penalty. Although the group as a whole had negative attitudes and views on the death penalty, greater positivity towards the death penalty was found in members of the male population who had a significantly more positive attitude towards the death penalty than women (Le Roux \& Ambrosio, 2007). Contrary to the results of previous studies, comparing differences in support for the death penalty and belief in criminological ideologies between the sexes among students in Bangladesh, China, Nigeria, and the US, no significant difference was found between men and women overall support levels or reasons. support or opposition to it between the sexes, except in the United States, where they were very pronounced. Accordingly, the authors concluded that the gender difference in terms of the death penalty may be limited to the United States (Lambert et al., 2014). Similar to heterosexuals, it has been found that most members of the gay and lesbian population support the death penalty (Worthen et al., 2012). In 
addition, the effects of gender and sexual orientation on attitudes toward the death penalty are mediated by political beliefs and empathic concerns (Worthen et al., 2012).

In further work, the consent of the respondents with certain reasons for not introducing the death penalty into the legal system of the Republic of Serbia was determined. In the first place, there are concerns about a possible wrongful conviction, then concerns about the impossibility of repeating the proceedings; reduction of punishment to naked repression; punishment would be revenge for the perpetrator; preference is given to laws over human rights and ultimately to the violation of human dignity. The conviction of factually innocent persons appears as a significant predictor of criminal attitudes in other relevant studies as well. For example, $\mathrm{Wu}$ (2021a) found a negative correlation between support for the death penalty and the rate of wrongfully convicted people, with respondents' belief in the existence of wrongful convictions and general concerns about the innocence of convicts not relevant to support / opposition to the death penalty, but their belief in the frequency of the same. Similarly, Norris \& Mullinix (2020) have shown that presenting the actual number of exemptions frees up support for the death penalty and undermines trust in the justice system, but fails to gain support for police reform or increase personal concern about wrongful convictions. However, the story of individual wrongful conviction has predictably had more pronounced effects on attitudes toward the death penalty and increases personal concern and support for police reform, but has a broad impact on trust in the justice system (Norris \& Mullinix, 2020). In addition to statistics, it has been found that attitudes are based not only on divorce motives, but also that correcting misconceptions related to the administration of the death penalty reduces support for it (Miske, Schweitzer, \& Horne, 2019). Finally, criminal justice practitioners across North Carolina, USA, despite awareness and agreement that they are innocent of the existence of wrongful convictions, were largely supported by the continued use of the death penalty (Hughes \& Robinson, 2013). Griffin (2021), comparing the reasons for support or opposition to the death penalty among American criminologists and those in the general public, found a high probability of opposition to the death penalty among experts, while the most common reasons for the opposition in both groups were moral beliefs. concerns about system errors and the unfair use of the death penalty. On the other hand, simple retributive justice was the dominant reason for supporting the death penalty, both among the general population and among a small minority of experts who expressed it (Griffin, 2021).

When it comes to the reasons that the respondents are guided by when deciding on the introduction of the death penalty, it was determined that in the first place: the impossibility of re-committing the crime, then deterring the perpetrator; a better expression of social condemnation for the crime committed; improving security; achieving proportionality and fairness between the committed crime and the gravity of the criminal sanction; economic consequences; lifelong life. Similarly, prospects of deterrence (Cao et al., 2020) and retaliation (Choi et al., 2019), revenge, instrumentalist goals, and disability have been identified as reasons for supporting the death penalty in previous studies (Lambert, Pasupuleti, et al., 2008). ). Nevertheless, Lambert, et al., (2008) pointed out that the dominant reasons for opposing the death penalty among the student population in India are morality and the belief that deterrence can be achieved by imposing life sentences without parole. Choi et al. (2019), in addition to the above, pointed out that factors such as the severity of the crime, security in the neighborhood, innocence, and the effect of brutality are negatively related to support for the death penalty. In contrast, those who believe in the effectiveness of rehabilitation tend to oppose the policy of the death penalty (Cao et al., 2020). While retaliation and instrumental perspectives are the leading creators of attitudes toward the death penalty in the United States, predictors of attitudes toward the death penalty in China, where there is strong support for it, are both instrumental and retributive perspectives, with the former being stronger (Jiang et al. 2009). In addition, Andreescu and Hughes (2020) found that opponents of the death penalty were less likely than criminal advocates to have criminal views at all or to express some dissatisfaction with government spending on crime control. 
When it comes to education, analyzes showed that respondents with a university degree scored the highest marks for trust in the legal system, while respondents with high school scored the highest marks for arguments: violation of human dignity; inability to repeat the procedure; the most serious crimes; public prosecutor's office; media. On the other hand, university graduates noticed the highest marks for arguments that give priority to laws about human rights, lifelong learning. Respondents with a master's or doctoral degree recorded the highest marks in the arguments of revenge for the perpetrator; economic consequences; expressing social condemnation for a crime; Police. The question of the relationship between education and the attitude towards the death penalty is unavoidable in a wide range of scientific studies (Kuehn, Ridener, \& Scott, 2018; Kuzina, Cherkasova, Artyukhin, Saraev, \& Comartov, 2020). The findings are inconsistent. While some studies (Vito, Keil, \& Andreescu, 1999) point out that opposition to the death penalty is more common among the highly educated, others (Thinley \& Ziegler Jr, 2020) indicate that education does not affect attitudes toward support for the death penalty. Contrary to previous insights into uninformed public prejudice as a source of public support for the death penalty (Chan, Tan, Lee, \& Mathi, 2018; Cochran \& Chamlin, 2005), Liu (2021) found that greater support for the death penalty is widespread among the elite. residents with higher education in China. Hessing, de Keijser, and Elffers (2003) also pointed out that advocates of the death penalty in the Netherlands are poorly educated and younger individuals (Kuzina et al., 2020). Manyok (2018) pointed out that with an increase in one level of education, the level of support for the death penalty decreases, while D'Agostino et al. (2018) identified general requirements for milder punishments for crimes among highly educated people living in less corrupt countries. Also, Vito et al. (1999) found that stability of support for the death penalty is associated with increased education and income.

The data generated by our research, which indicate that trust in the legal system decreases with age, support for the introduction of the death penalty, as well as the assessment of the efficiency of the competent authorities, are in line with previous studies (Hall, 2004; Vito et al., 1999). In addition, Tedrow (2016) found a greater likelihood of favoring the death penalty among veterans over non-veterans, while more frequent re-examination of someone's support and attitudes toward the death penalty due to facing the alternative is present in women, minorities, and people over 50 (Vito et al., 1999). In addition, they found an inverse relationship between support for the death penalty and the age of the victim (Dierenfeldt et al., 2020).

The conducted research has certain limitations, which are reflected in the following: a) insufficient representation of respondents included in the sample from different geographical areas of Serbia, bearing in mind that not everyone has access to the Internet; $b$ ) insufficiently covered set of demographic and socioeconomic factors that would be relevant for the conducted study (eg religiosity); c) additional research to examine additional aspects of the prediction model for the introduction of the death penalty; e) qualitative research with the heads of competent institutions.

\section{Conclusions}

Starting from the mentioned central hypothesis, the research confirmed that gender is one of the most important predictors of our model of citizens' attitudes about the risks of introducing the death penalty in the legal system. In addition, the research determined the unequivocal influence of education and marital status on certain aspects of citizens' attitudes about the introduction of such a punishment. Although the death penalty has not been applied in our country since 2002, the results have shown that the majority of citizens are in favor of its reintroduction, and they cite the impossibility of re-committing the crime as the main reason. Others who were not in favor of the introduction, as the main against the argument cited a possible wrongful conviction. Also, insufficient trust in the efficiency of the competent bodies that would 
be in charge of its implementation was noticed. Having in mind the importance of the conducted research, the competent state bodies should take into account the unequivocal attitudes of the citizens for the prescribed sanction to correspond to the social reality and public opinion. Certainly, even if there is a desire to introduce such a punishment, the obtained results show how an awareness-raising campaign can be implemented to accept or reject the introduction of such a punishment. At the same time, it is especially important to recognize the differences in attitudes at different levels of education, age, marital status, and income. The success of the implementation of such penalties will largely depend on broader public support and a clear determination of what is achieved through its introduction.

The presented model can be used for a more detailed understanding of people's attitudes regarding the support and opposition to the introduction of the death penalty in the legal system of the Republic of Serbia. That is why it is necessary to continue with continuous research for the legal system to more efficiently and better fulfill its purpose of existence in the processes of functioning of social communities. Also, the present model may be used for a better understanding of current penalties. This assumption is especially important when it comes to lifelong imprisonment, which is recently introduced (2019) in the Serbian legal system. This penalty in time of its introduction, according to parliamentary debate, was introduced as a kind of replacement for the death penalty in cases of sexual child abuse. Taking into consideration that the death penalty is not possible in countries that are a member of Council of Europe, as Serbia is, the members of Parliament opted for lifelong imprisonment in such cases.

Author Contributions: V.M.C. had the original idea for this study and developed the study design and questionnaire with T.B., B.R., G.M., and J.M. contributed to questionnaire dissemination, while V.M.C. and T.B. analyzed and interpreted the data. T. B. and G.M. made a special contribution by drafting the introduction; B.R. and J.M. have drafted the discussion and T.B. the conclusions. V.M.C., T.B., B.R., G.M., and J.M. critically reviewed the data analysis and contributed to the content for revising and finalizing the manuscript.

Funding: This research was funded by the Scientific-Professional Society for Disaster Risk Management, Belgrade, Serbia (http://upravljanje-rizicima.com/), International Institute for Disaster Research, Belgrade and Faculty of Law in Novi Sad.

Conflicts of Interest: The authors declare no conflict of interest.

\section{Appendix A}

Dear citizens, to better understand all the advantages and disadvantages of the introduction of the death penalty in the legal system of the Republic of Serbia, we will ask you to answer the questions we have prepared for you honestly and objectively. Please note that the questions are anonymous. On behalf of the scientific research team that conducts the research, which consists of professors from the Faculty of Law, the University of Novi Sad, and the Faculty of Security, University of Belgrade, we truly thank you for your time and support. After the research is completed, the research results will be published in one of the prestigious journals and available to you. Sincerely

\section{Socio-demographic characteristics}
1. Gender:
a) Male
b) Female

2. Age: (write number)

3. Marital status: a) single b) in connection (or engaged) c) married d) divorced (or widow)
4. Education level: a) Secondary school
c) High school
d) Undergraduate
e) Master / doctorate

5. Income level: a) Low income ( $\geq 500 \mathrm{EUR}) ; \mathrm{b})$ High income ( $\leq 500 \mathrm{EUR})$ 


\section{Citizens attitudes}

1. Please indicate the degree of agreement with the statements made, where 1 stands for "I strongly disagree" and 5 for "I strongly agree".

\begin{tabular}{|c|c|c|c|c|c|c|}
\hline No. & Statements & 1 & 2 & 3 & 4 & 5 \\
\hline 1. & I support the introduction of the death penalty in the RS legal system & 1 & 2 & 3 & 4 & 5 \\
\hline 2. & $\begin{array}{l}\text { I have confidence in the legal system of Serbia that would realize the execution of such a } \\
\text { criminal sanction? }\end{array}$ & 1 & 2 & 3 & 4 & 5 \\
\hline
\end{tabular}

2. Please indicate the degree of agreement with the statements made with reasons for introducing the death penalty, where 1 stands for "I strongly disagree" and 5 for "I strongly agree".

\begin{tabular}{clccccc}
\hline No. & Statements & $\mathbf{1}$ & $\mathbf{2}$ & $\mathbf{3}$ & $\mathbf{4}$ & $\mathbf{5}$ \\
\hline 1. & Improving security & $\mathbf{1}$ & $\mathbf{2}$ & $\mathbf{3}$ & $\mathbf{4}$ & $\mathbf{5}$ \\
2. & Impossibility to do the work again & $\mathbf{1}$ & $\mathbf{2}$ & $\mathbf{3}$ & $\mathbf{4}$ & $\mathbf{5}$ \\
3. & It deters perpetrators of crimes & $\mathbf{1}$ & $\mathbf{2}$ & $\mathbf{3}$ & $\mathbf{4}$ & $\mathbf{5}$ \\
4. & Life for life & $\mathbf{1}$ & $\mathbf{2}$ & $\mathbf{3}$ & $\mathbf{4}$ & $\mathbf{5}$ \\
5. & Economic repercussions & $\mathbf{1}$ & $\mathbf{2}$ & $\mathbf{3}$ & $\mathbf{4}$ & $\mathbf{5}$ \\
6. & Expressing social condemnation for a crime & $\mathbf{1}$ & $\mathbf{2}$ & $\mathbf{3}$ & $\mathbf{4}$ & $\mathbf{5}$ \\
7. & Achieving fairness and proportionality & $\mathbf{1}$ & $\mathbf{2}$ & $\mathbf{3}$ & $\mathbf{4}$ & $\mathbf{5}$ \\
\hline
\end{tabular}

3. Please indicate the degree of agreement with the statements made with reasons for not introducing the death penalty, where 1 stands for "I strongly disagree" and 5 for "I strongly agree".

\begin{tabular}{cllllll}
\hline No. & Statements & $\mathbf{1}$ & $\mathbf{2}$ & $\mathbf{3}$ & $\mathbf{4}$ & $\mathbf{5}$ \\
\hline 1. & Violation of human dignity & $\mathbf{1}$ & $\mathbf{2}$ & $\mathbf{3}$ & $\mathbf{4}$ & $\mathbf{5}$ \\
2. & Laws are preferred to human rights & $\mathbf{1}$ & $\mathbf{2}$ & $\mathbf{3}$ & $\mathbf{4}$ & $\mathbf{5}$ \\
3. & Wrongful condemnation & $\mathbf{1}$ & $\mathbf{2}$ & $\mathbf{3}$ & $\mathbf{4}$ & $\mathbf{5}$ \\
4. & Impossibility of repeating the procedure & $\mathbf{1}$ & $\mathbf{2}$ & $\mathbf{3}$ & $\mathbf{4}$ & $\mathbf{5}$ \\
5. & Reduced to mere repression & $\mathbf{1}$ & $\mathbf{2}$ & $\mathbf{3}$ & $\mathbf{4}$ & $\mathbf{5}$ \\
6. & Revenge for the perpetrator & $\mathbf{1}$ & $\mathbf{2}$ & $\mathbf{3}$ & $\mathbf{4}$ & $\mathbf{5}$ \\
\hline
\end{tabular}

4. Please indicate the degree of agreement with the statements made for which crimes would you envisage the death penalty, where 1 stands for "I strongly disagree" and 5 for "I strongly agree".

\begin{tabular}{cllllll}
\hline No. & Statements & $\mathbf{1}$ & $\mathbf{2}$ & $\mathbf{3}$ & $\mathbf{4}$ & $\mathbf{5}$ \\
\hline 1. & Aggravated murder & $\mathbf{1}$ & $\mathbf{2}$ & $\mathbf{3}$ & $\mathbf{4}$ & $\mathbf{5}$ \\
2. & The most serious crimes & $\mathbf{1}$ & $\mathbf{2}$ & $\mathbf{3}$ & $\mathbf{4}$ & 5 \\
3. & The most severe forms of heavy crime & $\mathbf{1}$ & $\mathbf{2}$ & $\mathbf{3}$ & $\mathbf{4}$ & $\mathbf{5}$ \\
\hline
\end{tabular}

5. Please indicate the degree of agreement with the statements made with the level of efficiency in the field of crime prevention or general prevention, where 1 stands for "I strongly disagree" and 5 for "I strongly agree". 


\begin{tabular}{clllllll}
\hline No. & Statements & $\mathbf{1}$ & $\mathbf{2}$ & $\mathbf{3}$ & $\mathbf{4}$ & $\mathbf{5}$ \\
\hline 1. & Police & $\mathbf{1}$ & $\mathbf{2}$ & $\mathbf{3}$ & $\mathbf{4}$ & 5 \\
2. & Public Prosecutor's Office & 1 & 2 & 3 & 4 & 5 \\
3. & Courts & 1 & 2 & 3 & 4 & 5 \\
4. & Media & 1 & 2 & 3 & 4 & 5 \\
\hline
\end{tabular}

\section{References}

Adinkrah, M., \& Clemens, W. M. (2018). To reinstate or to not reinstate? An exploratory study of student perspectives on the death penalty in Michigan. International journal of offender therapy and comparative criminology, 62(1), 229-252.

Anderson, A. L., Lytle, R., \& Schwadel, P. (2017). Age, period, and cohort effects on death penalty attitudes in the United States, 1974-2014. Criminology, 55(4), 833-868.

Andreescu, V., \& Hughes, T. T. (2020). Public opinion and the death penalty in Japan. Punishment \& Society, 22(5), 573-595.

Applegate, B. K., Wright, J. P., Dunaway, R. G., Cullen, F. T., \& Wooldredge, J. D. (1994). Victim-offender race and support for capital punishment: A factorial design approach. American Journal of Criminal Justice, 18(1), 95-115.

Armborst, A. (2017). How fear of crime affects punitive attitudes. European Journal on Criminal Policy and Research, 23(3), 461-481.

Arthur, J. A. (1998). Racial attitudes and opinions about capital punishment: Preliminary findings. International Journal of Comparative and Applied Criminal Justice, 22(1), 131-144.

Bailey, W. C. (1978). An analysis of the deterrent effect of the death penalty in North Carolina. NC Cent. LJ, $10,29$.

Baker, D. N., Lambert, E. G., \& Jenkins, M. (2005). Racial differences in death penalty support and opposition: A preliminary study of White and Black college students. Journal of Black Studies, 35(4), 201224.

Baker, J. O., \& Booth, A. L. (2016). Hell to pay: Religion and punitive ideology among the American public. Punishment \& Society, 18(2), 151-176.

Baker, J. O., \& Whitehead, A. L. (2020). God's penology: Belief in a masculine God predicts support for harsh criminal punishment and militarism. Punishment $\mathcal{E}$ Society, 22(2), 135-160.

Bedau, H. A. (2008). Death Penalty, Overview. In L. Kurtz (Ed.), Encyclopedia of Violence, Peace, \& Conflict (Second Edition) (pp. 541-546). Oxford: Academic Press.

Boateng, F. D., \& Dzordzormenyoh, M. K. (2021). Capital Punishment in Brazil: Exploring Factors That Predict Public Support for the Death Penalty. Journal of Contemporary Criminal Justice, 10439862211034345.

Bohm, R. M., Vogel, R. E., \& Maisto, A. A. (1993). Knowledge and death penalty opinion: A panel study. Journal of Criminal Justice, 21(1), 29-45. doi:https://doi.org/10.1016/0047-2352(93)90004-7

Bones, P. D. C., \& Sabriseilabi, S. (2018). Sinners in the hands of an angry God: An exploration of religious forces on support for the death penalty. Journal for the Scientific Study of Religion, 57(4), 707-722.

Brace, P., \& Boyea, B. D. (2008). State public opinion, the death penalty, and the practice of electing judges. American Journal of Political Science, 52(2), 360-372.

Britto, S., \& Noga-Styron, K. E. (2014). Media consumption and support for capital punishment. Criminal Justice Review, 39(1), 81-100. 
Cao, L., Lai, Y.-L., \& Huang, C.-C. (2020). Exploring sources of public attitudes toward capital punishment in Taiwan. Crime, Law and Social Change, 74(5), 571-588.

Chan, W.-C., Tan, E. S., Lee, J. T.T., \& Mathi, B. (2018). How strong is public support for the death penalty in Singapore? Asian journal of criminology, 13(2), 91-107.

Chen, D. L. (2017). The deterrent effect of the death penalty? Evidence from British commutations during World War I. Evidence from British Commutations During World War I (Feb 26, 2017).

Chintakrindi, S., \& Porter, J. (2016). Assisted Suicide and the Death Penalty: Examining Attitudes towards State Sanctioned Death. Kriminologija \& socijalna integracija: časopis za kriminologiju, penologiju $i$ poremé́aje u ponašanju, 24(2), 1-23.

Choi, E., Jiang, S., \& Lambert, E. G. (2019). Reasons for South Korean attitudes towards the death penalty: exploring the nexus between strong public support and history of misapplication. International Journal of Comparative and Applied Criminal Justice, 43(1), 61-76.

Cochran, J. K., \& Chamlin, M. B. (2005). Can information change public opinion? Another test of the Marshall hypotheses. Journal of Criminal Justice, 33(6), 573-584.

Cochran, J. K., \& Sanders, B. A. (2009). The gender gap in death penalty support: An exploratory study. Journal of Criminal Justice, 37(6), 525-533.

Cochran, J. K., Chamlin, M. B., \& Seth, M. (1994). Deterrence or brutalization? An impact assessment of Oklahoma's return to capital punishment. Criminology, 32(1), 107-134.

Cochran, J. K., Marier, C. J., Jennings, W. G., Smith, M. D., Bjerregaard, B., \& Fogel, S. J. (2019). Rape, race, and capital punishment: an enduring cultural legacy of lethal vengeance? Race and justice, 9(4), 383-406.

Cohen-Cole, E., Durlauf, S., Fagan, J., \& Nagin, D. (2009). Model uncertainty and the deterrent effect of capital punishment. American Law and Economics Review, 11(2), 335-369.

Colucci, A. R. (2020). Capital Punishment. In A. Kobayashi (Ed.), International Encyclopedia of Human Geography (Second Edition) (pp. 9-14). Oxford: Elsevier.

Cox, A. K. (2013). Student death penalty attitudes: Does new information matter? Journal of Criminal Justice Education, 24(4), 443-460.

Cvetkovic, V., \& Martinović, J. (2021). Innovative solutions for flood risk management. International Journal of Disaster Risk Management, 2(2), 71-100. https://doi.org/10.18485/ijdrm.2020.2.2.5

Cvetković, V., Nikolić, N., Nenadić, R. U., Ocal, A., \& Zečević, M. (2020). Preparedness and Preventive Behaviors for a Pandemic Disaster Caused by COVID-19 in Serbia. International journal of environmental research and public health, 17(11), 4124.

D'Agostino, E., Sironi, E., \& Sobbrio, G. (2018). Individual and contextual factors in determining attitudes towards crime and punishment. Recent Advances in Information Technology, Tourism, Economics, Management and Agriculture, 1141.

Dambrun, M. (2007). Understanding the relationship between racial prejudice and support for the death penalty: The racist punitive bias hypothesis. Social Justice Research, 20(2), 228-249.

Decker, S. H., \& Kohfeld, C. W. (1990). The deterrent effect of capital punishment in the five most active execution states: A time series analysis. Criminal Justice Review, 15(2), 173-191.

Dezhbakhsh, H., \& Shepherd, J. M. (2006). The deterrent effect of capital punishment: Evidence from a "judicial experiment". Economic Inquiry, 44(3), 512-535.

Dezhbakhsh, H., Rubin, P. H., \& Shepherd, J. M. (2003). Does capital punishment have a deterrent effect? New evidence from postmoratorium panel data. American Law and Economics Review, 5(2), 344-376.

Dierenfeldt, R., Scott, S., Iles, G., Rosenberger, J., \& Smith, M. (2020). Support for the death penalty in cases of rape and sexual assault: variation between victim age categories. International journal of offender therapy and comparative criminology, 0306624 X20983742.

Dotson, H., \& Carter, J. S. (2012). Changing views toward the death penalty? The intersecting impact of race and gender on attitudes, 1974-2006. Justice System Journal, 33(1), 1-21. 
Ehrlich, I. (1973). The deterrent effect of capital punishment: A question of life and death (0898-2937). Retrieved from

Ellsworth, P. C., \& Gross, S. R. (1997). Hardening of the attitudes: Americans views on the death penalty. The death penalty in America: Current controversies, 90-115.

Foglia, W. D., \& Connell, N. M. (2019). Distrust and empathy: Explaining the lack of support for capital punishment among minorities. Criminal Justice Review, 44(2), 204-230.

Forst, B. (1983). Capital punishment and deterrence: Conflicting evidence. J. Crim. L. \& Criminology, 74, 927.

Gau, J. M., \& Wiecko, F. M. (2010). Hell hath no fury: a gender-dichotomized analysis predicting prolife/pro-death penalty attitudes.

Gerber, M. M. (2021). Attitudes toward punishment. In Oxford Research Encyclopedia of Criminology and Criminal Justice.

Godcharles, B. D., Rad, J. D. J., Heide, K. M., Cochran, J. K., \& Solomon, E. P. (2019). Can empathy close the racial divide and gender gap in death penalty support? Behavioral sciences $\mathcal{E}$ the law, 37(1), 16-37.

Grasmick, H. G., Bursik Jr, R. J., \& Blackwell, B. S. (1993). Religious beliefs and public support for the death penalty for juveniles and adults. Journal of Crime and Justice, 16(2), 59-86.

Grasmick, H. G., Cochran, J. K., Bursik Jr, R. J., \& Kimpel, M. L. (1993). Religion, punitive justice, and support for the death penalty. Justice Quarterly, 10(2), 289-314.

Griffin, T. (2021). Comparing expert versus general public rationale for death penalty support and opposition: Is expert perspective on capital punishment consistent with "disciplined retention"? Punishment \& Society, 14624745211029370.

Hall, P. T. M. (2004). Be still my heart: Determinants of support for capital punishment attitudes.

Haney, C., Weill, J., \& Lynch, M. (2015). The death penalty. In B. L. Cutler \& P. A. Zapf (Eds.), APA handbook of forensic psychology, Vol. 2. Criminal investigation, adjudication, and sentencing outcomes (pp. 451-510). American Psychological Association. https://doi.org/10.1037/14462-017

Hannan, K. R., Cullen, F. T., Butler, L. C., Graham, A., Burton, A. L., \& Burton Jr, V. S. (2021). Racial sympathy and support for capital punishment: A case study in concept transfer. Deviant Behavior, 1-24.

Hanslmaier, M., \& Baier, D. (2016). Re-examining the relationship between religion and punitiveness: Evidence from Germany. European journal of criminology, 13(4), 473-490.

Hartnagel, T. F., \& Templeton, L. J. (2012). Emotions about crime and attitudes to punishment. Punishment $\mathcal{E}$ Society, 14(4), 452-474.

Heiberger, R. M., \& Neuwirth, E. (2009). One-Way ANOVA. In M. Richard \& E. N. Heiberger (Eds.), $R$ through excel (pp. 165-191). New York, NY: Springer.

Hessing, D. J., de Keijser, J. W., \& Elffers, H. (2003). Explaining capital punishment support in an abolitionist country: The case of the Netherlands. Law and Human Behavior, 27(6), 605-622.

Hjalmarsson, R. (2009). Does capital punishment have a "local" deterrent effect on homicides? American Law and Economics Review, 11(2), 310-334.

Howells, G. N., Flanagan, K. A., \& Hagan, V. (1995). Does viewing a televised execution affect attitudes toward capital punishment? Criminal Justice and Behavior, 22(4), 411-424.

Hughes, C. C., \& Robinson, M. (2013). Perceptions of law enforcement officers on capital punishment in the United States. International Journal of Criminal Justice Sciences, 8(2), 153.

Hurwitz, J., \& Smithey, S. (1998). Gender differences on crime and punishment. Political Research Quarterly, 51(1), 89-115.

Janković, B. (2021). The role of the police in disasters caused by pandemic infectious diseases. International Journal of Disaster Risk Management, 3(1), 41-50.

Jiang, S., Hu, M., \& Lambert, E. G. (2018). Predictors of death penalty views in China: An empirical comparison between college students and citizens. International journal of offender therapy and comparative criminology, 62(14), 4714-4735. 
Jiang, S., Lambert, E. G., \& Nathan, V. M. (2009). Reasons for death penalty attitudes among Chinese citizens: Retributive or instrumental? Journal of Criminal Justice, 37(3), 225-233.

Jiang, S., Lambert, E. G., Wang, J., Saito, T., \& Pilot, R. (2010). Death penalty views in China, Japan and the US: An empirical comparison. Journal of Criminal Justice, 38(5), 862-869.

Jiang, S., Pilot, R., \& Saito, T. (2010). Why Japanese support the death penalty? International Criminal Justice Review, 20(3), 302-316.

Jou, S., \& Hebenton, B. (2019). Support for the Death Penalty in Taiwan?: a Study of Value Conflict and Ambivalence. Asian journal of criminology, 1-21.

Kamble, S., \& Mullet, E. (2016). A mapping of young Hindu's views on the appropriateness of the Death Penalty as a function of circumstances of crime. International Journal of Law, Crime and Justice, 44, 14-25.

Kandola, S. S., \& Egan, V. (2014). Individual differences underlying attitudes to the death penalty. Personality and individual differences, 66, 48-53.

Keil, T. J., \& Vito, G. F. (1991). Fear of crime and attitudes toward capital punishment: A structural equations model. Justice Quarterly, 8(4), 447-464.

Kelley, J., \& Braithwaite, J. (1990). Public opinion and the death penalty in Australia. Justice Quarterly, 7(3), 529-563.

Kennedy, S. C., \& Tripodi, S. J. (2015). The death penalty attitudes of social work students: current and future opportunities. Journal of Forensic Social Work, 5(1-3), 201-233.

Kim, T. K. (2015). T test as a parametric statistic. Korean Journal of Anesthesiology, 68(6), 540-546. https://doi.org/ 10.4097/kjae.2015.68.6.540.

Kornhauser, R. (2015). Economic individualism and punitive attitudes: A cross-national analysis. Punishment \& Society, 17(1), 27-53.

Kort-Butler, L. A., \& Ray, C. M. (2019). Public support for the death penalty in a red state: The distrustful, the angry, and the unsure. Punishment \& Society, 21(4), 473-495.

Krstić, Ž. (2012). Istorijska sociologija zatvora u Srbiji: Od okova do " narukvice". Sociološki pregled, 46 (34), 1046-1070.

Kuehn, S., Ridener, R. J., \& Scott, P. W. (2018). Do criminology classes make a difference? Changes in perceptions of punishment over time. Journal of Criminal Justice Education, 29(1), 1-17.

Kuzina, S. I., Cherkasova, T. P., Artyukhin, O. A., Saraev, N. V., \& Comartov, D. S. (2020). Political-legal issues of fulfillment of russia's international obligations on death penalty abolition in the country. Revista Gênero e Direito, 9(S3), 178-200.

Lambert, E. G., Camp, S. D., Clarke, A., \& Jiang, S. (2011). The impact of information on death penalty support, revisited. Crime \& Delinquency, 57(4), 572-599.

Lambert, E. G., Clarke, A., Tucker-Gail, K. A., \& Hogan, N. L. (2009). Multivariate analysis of reasons for death penalty support between male and female college students: empirical support for Gilligan's 'ethic of care'. Criminal Justice Studies, 22(3), 239-260.

Lambert, E. G., Hogan, N. L., Moore, B., Jenkins, M., Jiang, S., \& Clarke, A. (2008). The death penalty attitudes of criminal justice students: Are they different from other students? Criminal Justice Studies, 21(2), 193-212.

Lambert, E. G., Jiang, S., Elechi, O. O., Khondaker, M. I., Baker, D. N., \& Jin, W. (2014). A preliminary study of gender differences in death penalty views of college students from Bangladesh, China, Nigeria, and the United States. Journal of Ethnicity in Criminal Justice, 12(1), 44-68.

Lambert, E. G., Jiang, S., Williamson, L. C., Elechi, O. O., Khondaker, M. I., Baker, D. N., \& Saito, T. (2016). Gender and capital punishment views among Japanese and US college students. International Criminal Justice Review, 26(4), 337-358.

Lambert, E. G., Pasupuleti, S., Jiang, S., Jaishankar, K., \& Bhimarasetty, J. V. (2008). Views on the death penalty among college students in India. Punishment \& Society, 10(2), 207-218. 
Le Roux, A., \& Ambrosio, C. (2007). The influence of gender, age and race on the attitude of South Africans towards the death penalty. Acta Criminologica: African Journal of Criminology \& Victimology, 20(1), 35-54.

Lehmann, P. S., \& Pickett, J. T. (2017). Experience versus expectation: Economic insecurity, the great recession, and support for the death penalty. Justice Quarterly, 34(5), 873-902.

Li, Y., Longmire, D., \& Lu, H. (2018). Death penalty disposition in China: what matters? International journal of offender therapy and comparative criminology, 62(1), 253-273.

Liang, B., Liu, J., \& Lu, H. (2019). Variability of death penalty attitude in China: an empirical test of the Marshall hypotheses. Crime, Law and Social Change, 72(3), 269-302.

Liu, J. Z. (2021). Public Support for the Death Penalty in China: Less from the Populace but More from Elites. The China Quarterly, 246, 527-544.

Lopez, R. (2014). Exploring Disparities in Women, Gender, and the Death Penalty.

Lytle, R., \& ten Bensel, T. (2016). Are self-identified Christian fundamentalists really more supportive of capital punishment? Exploring the relationship between fundamentalism and death penalty attitudes. Criminal Justice Studies, 29(4), 309-324.

Maggard, S. R., Payne, B. K., \& Chappell, A. T. (2012). Attitudes toward capital punishment: Educational, demographic, and neighborhood crime influences. The Social Science Journal, 49(2), 155-166.

Mangum, M. (2019). Testing the influence of social capital on support for the death penalty. Social Justice Research, 32(4), 431-444.

Mannes, S., \& Ingaglio Jr, R. (2015). A Film is Worth a Thousand Words: The Impact of Film, Need for Cognition, and Experiential Thinking on Attitudes towards the Death Penalty. North American Journal of Psychology, 17(2).

Manyok, P. T. (2018). Capital Punishment. Journal of Social and Political Science, 1(5). 1-21.

Mathias, M. D. (2013). The sacralization of the individual: Human rights and the abolition of the death penalty. American Journal of Sociology, 118(5), 1246-1283.

Medwed, D. S. (2020). Black Deaths Matter: The Race-of-Victim Effect and Capital Punishment. Northeastern University School of Law Research Paper(367-2020).

Miller, M. K., \& Hayward, R. D. (2008). Religious characteristics and the death penalty. Law and Human Behavior, 32(2), 113-123.

Narayan, P. K., \& Smyth, R. (2006). Dead man walking: an empirical reassessment of the deterrent effect of capital punishment using the bounds testing approach to cointegration. Applied Economics, 38(17), 19751989.

Norrander, B. (2000). The multi-layered impact of public opinion on capital punishment implementation in the American states. Political Research Quarterly, 53(4), 771-793.

Norris, R. J., \& Mullinix, K. J. (2020). Framing innocence: An experimental test of the effects of wrongful convictions on public opinion. Journal of Experimental Criminology, 16(2), 311-334.

Passell, P. (1975). The deterrent effect of the death penalty: A statistical test. Stan. L. Rev., 28, 61.

Passell, P., \& Taylor, J. B. (1977). The deterrent effect of capital punishment: Another view. The American Economic Review, 67(3), 445-451.

Peshkopia, R., \& Stephen Voss, D. (2016). The role of ethnic divisions in people's attitudes toward the death penalty: The case of the Albanians. Punishment \& Society, 18(5), 610-630.

Peshkopia, R., \& Trahan, A. (2020). Support for the Death Penalty Reinstatement as a Protest Attitude: The Role of Political Trust. International Criminal Justice Review, 1057567720963158.

Peshkopia, R., \& Voss, D. S. (2016). Attitudes toward the death penalty in ethnically divided societies: Albania, Macedonia, and Montenegro. Journal of Behavioral and Social Sciences, 3(1), 29-40.

Phillips, D. P. (1980). The deterrent effect of capital punishment: New evidence on an old controversy. American Journal of Sociology, 86(1), 139-148.

Phillips, S. (2009). Status disparities in the capital of capital punishment. Law \& Society Review, 43(4), 807838. 
Rade, C. B., Holland, A. M., Gregory, J. B., \& Desmarais, S. L. (2017). Systematic review of religious affiliations and beliefs as correlates of public attitudes toward capital punishment. Criminal Justice Studies, 30(1), 63-85.

Rafiq, J. (2020). Death Penalty, whether justified or not: A critical Analysis. Journal of Human Rights Law and Practice, 3(2), 1-25.

Rancourt, M. A., Ouellet, C., \& Dufresne, Y. (2020). Is the Death Penalty Debate Really Dead? Contrasting Capital Punishment Support in Canada and the United States. Analyses of Social Issues and Public Policy, 20(1), 536-562.

Robbers, M. (2006). Tough-mindedness and fair play: Personality traits as predictors of attitudes toward the death penalty-an exploratory gendered study. Punishment $\mathcal{E}$ Society, 8(2), 203-222.

Shepherd, J. M. (2004). Murders of passion, execution delays, and the deterrence of capital punishment. The Journal of Legal Studies, 33(2), 283-321.

Singer, A. J., Chouhy, C., Lehmann, P. S., Stevens, J. N., \& Gertz, M. (2020). Economic anxieties, fear of crime, and punitive attitudes in Latin America. Punishment \& Society, 22(2), 181-206.

Soss, J., Langbein, L., \& Metelko, A. R. (2003). Why do white Americans support the death penalty? The Journal of Politics, 65(2), 397-421.

Steele, T., \& Wilcox, N. (2003). A view from the inside: The role of redemption, deterrence, and masculinity on inmate support for the death penalty. Crime \& Delinquency, 49(2), 285-312.

Stojanović, Z. (2013). Krivično pravo - opšti deo. Beograd: Pravni fakultet.

Stokes, E. C., Haynes, S. H., Burdette, A. M., \& May, D. C. (2020). Punishing the Wrongdoers: The Effects of Religiosity on Punitive Attitudes toward Adults and Juveniles. Sociological Focus, 53(4), 411-427.

Tabachnick, B. G., Fidell, L. S., \& Ullman, J. B. (2007). Using Multivariate Statistics (5th ed.). Boston, MA: Pearson.

Tedrow, L. (2016, April). The Lingering Effects of Major Life Course Events: Veteran Status and Attitudes Toward Capital Punishment in the New Millennium. In 2016 Annual Meeting. PAA.

Thinley, T., \& Ziegler Jr, A. H. (2020). Attitudes Toward Capital Punishment in America: An Analysis of Survey Data.

Trahan, A. (2017). Public attitudes toward legal abortion, euthanasia, suicide, and capital punishment: partial evidence of a consistent life ethic. Criminal Justice Review, 42(1), 26-41.

Trahan, A., \& Laird, K. (2018). The nexus between attribution theory and racial attitudes: a test of racial attribution and public opinion of capital punishment. Criminal Justice Studies, 31(4), 352-367.

Tripunović, Đorđija (1988): Umlje i bezumlje (prilog izučavanju smrtne kazne), Beograd: Narodna knjiga, Novi Sad: Književna zajednica.

Unnever, J. D., \& Cullen, F. T. (2006). Christian fundamentalism and support for capital punishment. Journal of Research in Crime and Delinquency, 43(2), 169-197.

Unnever, J. D., Cullen, F. T., \& Bartkowski, J. P. (2006). Images of God and public support for capital punishment: Does a close relationship with a loving God matter? Criminology, 44(4), 835-866.

Unnever, J. D., Cullen, F. T., \& Fisher, B. S. (2005). Empathy and public support for capital punishment. Journal of Crime and Justice, 28(1), 1-34.

Unnever, J. D., Cullen, F. T., \& Jonson, C. L. (2008). Race, racism, and support for capital punishment. Crime and Justice, 37(1), 45-96.

Updegrove, A. H. (2019). Acculturation and capital punishment: The effect of Mexico versus United States cultural orientations on public support for the death penalty. International journal of offender therapy and comparative criminology, 63(8), 1220-1241.

Van Koppen, P. J., Hessing, D. J., \& De Poot, C. J. (2002). Public reasons for abolition and retention of the death penalty. International Criminal Justice Review, 12(1), 77-92.

Vito, G. F., Keil, T. J., \& Andreescu, V. (1999). Kentuckians' changes in attitudes toward death penalty. Criminal Justice Studies, 12(2), 123-143. 
Vollum, S., Longmire, D. R., \& Buffington-Vollum, J. (2004). Confidence in the death penalty and support for its use: Exploring the value-expressive dimension of death penalty attitudes. Justice Quarterly, 21(3), 521-546.

Vollum, S., Mallicoat, S., \& Buffington-Vollum, J. (2009). Death Penalty Attitudes in an Increasingly Critical Climate: Value-Expressive Support and Attitude Mutability. Southwest Journal of Criminal Justice, 5(3).

Webster, R. J., \& Saucier, D. A. (2013). Angels and demons are among us: Assessing individual differences in belief in pure evil and belief in pure good. Personality and Social Psychology Bulletin, 39(11), 1455-1470.

Whitehead, J. T., \& Blankenship, M. B. (2000). The gender gap in capital punishment attitudes: An analysis of support and opposition. American Journal of Criminal Justice, 25(1), 1-13.

Wiecko, F. M., \& Gau, J. M. (2008). Every life is sacred kind of: Uncovering the sources of seemingly contradictory public attitudes toward abortion and the death penalty. The Social Science Journal, 45(4), 546-564.

Williams, K. E. G., Votruba, A. M., Neuberg, S. L., \& Saks, M. J. (2019). Capital and punishment: Resource scarcity increases endorsement of the death penalty. Evolution and Human Behavior, 40(1), 65-73.

Worthen, M. G. F., Sharp, S. F., \& Rodgers, F. R. (2012). Gay and lesbian individuals' attitudes toward the death penalty: An exploratory study of the roles of empathic concern and political beliefs. Criminal Justice Review, 37(2), 239-261.

Wozniak, K. H., \& Lewis, A. R. (2010). Reexamining the effect of Christian denominational affiliation on death penalty support. Journal of Criminal Justice, 38(5), 1082-1089.

Wu, S. (2021a). The Effect of Wrongful Conviction Rate on Death Penalty Support and How It Closes the Racial Gap. American Journal of Criminal Justice, 1-19.

$\mathrm{Wu}, \mathrm{S}$. (2021b). The effect of wrongful conviction rate on death penalty support: a research note. Journal of Experimental Criminology, 1-14.

$\mathrm{Wu}, \mathrm{Y}$., Sun, I. Y., \& Wu, Z. (2011). Support for the death penalty: Chinese and American college students compared. Punishment \& Society, 13(3), 354-376.

Yuan, M., Ekici, A., Lu, Z., \& Monteiro, R. (2007). Dimension reduction and coefficient estimation in multivariate linear regression. Journal of the Royal Statistical Society: Series B (Statistical Methodology), 69(3), 329-346. https://doi.org/10.1111/j.1467-9868.2007.00591.x

Zalman, M., Larson, M. J., \& Smith, B. (2012). Citizens' attitudes toward wrongful convictions. Criminal Justice Review, 37(1), 51-69. 